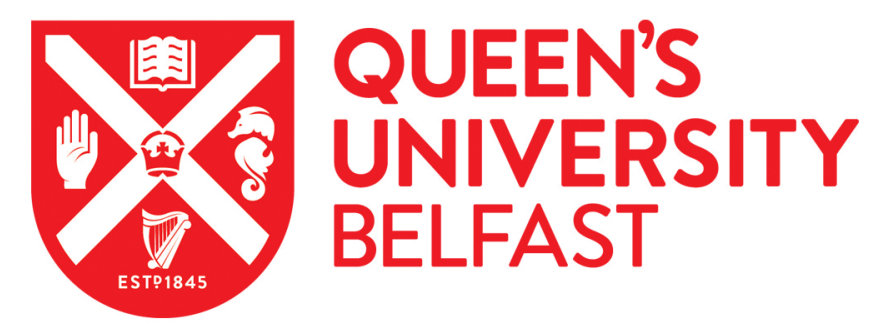

\title{
CFD Modelling of Almond Drying in a Tray Dryer
}

Chilka, A. G., \& Ranade, V. V. (2018). CFD Modelling of Almond Drying in a Tray Dryer. Canadian Journal of Chemical Engineering , 1-13. https://doi.org/10.1002/cjce.23357

Published in:

Canadian Journal of Chemical Engineering

Document Version:

Peer reviewed version

Queen's University Belfast - Research Portal:

Link to publication record in Queen's University Belfast Research Portal

Publisher rights

(c) 2018 Canadian Society for Chemical Engineering. This work is made available online in accordance with the publisher's policies. Please refer to any applicable terms of use of the publisher.

\section{General rights}

Copyright for the publications made accessible via the Queen's University Belfast Research Portal is retained by the author(s) and / or other copyright owners and it is a condition of accessing these publications that users recognise and abide by the legal requirements associated with these rights.

Take down policy

The Research Portal is Queen's institutional repository that provides access to Queen's research output. Every effort has been made to ensure that content in the Research Portal does not infringe any person's rights, or applicable UK laws. If you discover content in the Research Portal that you believe breaches copyright or violates any law, please contact openaccess@qub.ac.uk. 


\title{
CFD Modelling of Almond Drying in a Tray Dryer
}

\author{
Amarvir G. Chilka ${ }^{1,2}$ and Vivek V. Ranade ${ }^{*, 2,3}$ \\ ${ }^{1}$ Chemical Engineering and Process Development Division \\ CSIR - National Chemical Laboratory \\ Pune 411008, INDIA \\ ${ }^{2}$ Academy of Scientific and Innovative Research (AcSIR), CSIR-National Chemical Laboratory \\ (CSIR-NCL) Campus, Pune 411008, INDIA \\ ${ }^{3}$ School of Chemistry and Chemical Engineering \\ Queen's University Belfast, Belfast, NI, UK \\ *Email: V.Ranade@qub.ac.uk
}

\begin{abstract}
Drying is important in many food processing applications, and particularly so in the dry fruits industry. This work is focused on developing computational models for simulating drying of almonds in a tray dryer. It is important to quantitatively understand heat and mass transfer within and around single almond particle as well as particle - particle interactions and their implications for dryer design. In this work, we have developed a systematic CFD modelling framework for modelling almond drying in a tray dryer. A single tray filled with almonds $(\sim 2 \mathrm{~kg})$ were dried at three set temperatures viz., 55, 65 and $75{ }^{\circ} \mathrm{C}$. Air relative humidity at inlet, outlet locations, and weight of almonds were measured to quantify the moisture loss of almonds for each experiment. An additional set of experiments were conducted in which almonds were filled only in the half section of tray, keeping the other half empty. Same amount of almonds were used, to have multiple layers of almonds in the tray and the set temperature for the experiment was $75{ }^{\circ} \mathrm{C}$. Flow, heat and mass transfer in tray dryer were simulated using commercial CFD software Ansys Fluent. The values of effective diffusivity and average heat transfer coefficient determined from single and multiple particle system, were used for tray dryer simulations. The simulated results were compared with the experimental measurements. The validated computational model was used to simulate various cases including larger and more trays. The developed approach and models will be useful to select appropriate dryer configuration and optimize its design. The developed models will also be useful to identify suitable operation conditions for drying of almonds as well as other food products.
\end{abstract}

Keywords: CFD, drying, almonds, tray dryer, mal-distribution, scale-up 


\section{Introduction}

Drying is one of the most widely used unit operation in food industry. Drying serves many purposes related to preservation and other quality attributes. Drying is a complex process which involves supply of heat, transfer of moisture within the product to its surface and later into the surrounding medium, which is generally air. Heat and mass transfer are coupled and needs to be understood appropriately for the food product being dried. Chemical/biochemical composition of every food product is different, and it may undergo changes during drying process. It is important to develop models for simulating drying operation to enable appropriate design and scale - up of industrial dryers.

Traditionally drying kinetics of food products is described using empirical and semi-empirical models. These could be single parameter Newton model given by Ayenus ${ }^{[1]}$, two parameter Page model given by Karathanos et al. ${ }^{[2]}$, two term exponential models given by Akpinar et al. ${ }^{[3]}$, Verma et al. ${ }^{[4]}$ and Midilli et al. ${ }^{[5]}$. These models do not account for the influence of flow and transport properties, which are based on the geometrical configuration and operating parameters. Hence applicability of these models for prediction of drying behaviour in large scale units is limited. Analysing flow and heat and mass transport in the drying unit provides more detailed understanding on the variation of moisture in the food product. Computational fluid dynamics (CFD) based simulations provide detailed information on the variation in flow and temperature, within the drying unit. Based on these results variations in heat and mass transfer could be analysed. Ranjbaran et al. ${ }^{[6]}$ have simulated deep-bed paddy drying by using drying kinetics model coupled with CFD simulations. The variation in heat and mass transfer properties around the food particle was studied by Kaya et al. ${ }^{[7]}$ and ElGamal et al. ${ }^{[8]}$ considering kiwi fruit and single rice kernel respectively. From these studies it has been shown that variation in heat and mass transfer properties is important for accurate prediction of drying behaviour.

Almonds are the food product considered in this study. In our earlier work (Chilka and Ranade ${ }^{[9,10]}$ ) detailed analysis for drying of single and multiple almond particles was carried out. Drying behaviour of a single almond particle, eight and twenty-seven almond particles arranged in $2 \times 2 \times 2$ and $3 \times 3 \times 3$ configurations were studied. The flow, heat and mass transfer characteristics of this widely used moisture analyzer were simulated using CFD model. Simulations were carried out using the commercial CFD software, FLUENT (of Ansys Inc.). User defined functions were used to implement additional appropriate drying models. The model and simulated results show good agreement with the experimental data. Geometry of almond particles was considered in the simulations and detailed flow and heat and mass transfer coefficients were simulated for all the particles. The results were used to understand particle - particle interactions and their influence on heterogeneity on drying behaviour in a group of almond particles. In this work, the understanding and models from the single and multiparticle studies were used and extended to simulate performance of a tray dryer. 
Considering the importance of drying to product quality and costs involved in drying process, design of a large-scale dryer needs to be evaluated thoroughly. Understanding the drying characteristics in terms of overall drying time, moisture variation at the end of drying cycle, range of operating envelope, etc. will help to improve design of drying equipment. Computational modelling is a feasible and practically viable option that could be used to evaluate various dryer configurations. This in turn requires development of reliable computational models that could capture the drying characteristics close to the experimental measurements. The drying model should be applicable over a wide range of drying operations, and different dryer configurations. Various types of dryers are used for drying of agricultural food products. Tray dryers are most commonly used, due to its simple design and ease of operation. In this design multiple trays are filled with food product to be dried, hot air is used as drying medium to achieve the desired moisture levels. In this work, we have considered drying of almonds in a tray dryer. Drying model has been developed to predict the moisture and almond temperature using CFD framework.

Results from CFD simulations provide insights into moisture distribution on the tray during the drying process. Unlike simplified 1D models which only provide variation of overall average moisture content during the drying process, the CFD simulations capture the spatio-temporal variation in moisture content due to the influence of key process parameters like velocity, temperature and air humidity. Prediction of change in air humidity during the drying process will enable to evaluate the drying characteristics for various air quality, and to check if there could be reverse transfer of moisture from air to particles. Drying experiments were carried out in tray dryer to generate data with which developed CFD models may be evaluated.

Tray dryers have been traditionally modelled using 1D mathematical models to predict the drying characteristics. Colak et al. ${ }^{[11]}$ have presented 1D mathematical modelling for drying and Aviara et al. ${ }^{[12]}$ have presented energy and exergy analyses for green olive and cassava starch respectively in a tray dryer. The advantage of this modelling approach is they could be executed quickly, with less computational resources. However, these models provide overall drying characteristics in a tray dryer. These models also consider uniform air flow over the complete tray. In the real operation depending upon the configuration of tray dryer, there could be a variation in air flow distribution. For tray dryer systems it is important to understand the air flow distribution and its influence on the drying characteristics of the food product. Margaris et al. ${ }^{[13]}$ have shown with the help of CFD analysis, improving air flow distribution in tray dryers, showed improved dried product quality. Evaluation of various turbulence models was done to compare the measured and predicted data. Based on their analysis they showed that standard k- $\varepsilon$ turbulence model is the most adequate turbulence model. There are published studies which show the application of CFD for improving the air flow and temperature 
distribution in tray dryers. Amanlou ${ }^{[14]}$ has applied CFD for designing a new fruit cabinet dryer. Misha et al. ${ }^{[15]}$ have provided review on the applications of tray dryer and showed significance of CFD tool for improving its design. Most of these models however have focussed in analysing air flow within the dryer and did not account for coupling between airflow and moisture content of the material being dried. In the current study, we have developed detailed CFD model which accounts for the inherent coupling between moisture content of the material being dried and air flow, temperature distribution around it. Specific experiments were carried out to evaluate the developed computational models. Drying experiments were conducted for three set temperatures of 55,65 and $75{ }^{\circ} \mathrm{C}$, for a single tray filled with almonds weighing $2 \mathrm{~kg}$. Measurements of air temperature, inlet and outlet air relative humidity along with weight of almonds during each drying experiment were carried out. Additional experiments were conducted, where almonds were filled only in the half-section of the tray. CFD based model for drying of almonds was implemented using User Defined Functions (UDFs) to capture the moisture and temperature variation of almonds during drying. Simulation predicted results were validated against the experimentally measured values. Details on experimental setup along with procedure, modelling details and results are described in the following sections. The validated computational model was then used to understand influence of scale and number of trays on drying performance. The developed modelling approach of fully coupled drying model for flow, heat transfer and drying will be useful to understand the drying characteristics and to evaluate various industrial scale dryers.

\section{Experimental}

Experiments were conducted using a $3 \mathrm{~kW}$ tray dryer, to study the bulk drying kinetics of almond kernels. Details of the unit, experimental procedure, estimation of error bars, and processing of experimental data are described in the following sections.

\subsection{Tray dryer unit}

A Tray dryer unit having six heating coils each of $500 \mathrm{~W}$, along with four trays section and a fan to circulate air was used to perform drying experiments. Figure 1a shows the schematic of the Tray dryer unit. There are three major sections of the unit, ambient air inlet enters from the bottom left side. In the first section there are three heating coils, second is the tray section, it could accommodate maximum of four trays and the last section has three heating coils along with a fan to exhaust air out of the unit. For drying experiments, a single tray completely filled with almonds was used. The unit has a temperature controller with the provision to set the desired temperature. The heating coils were switched on and off through the temperature controller depending on the change in the temperature within the unit. There is an additional safety controller which allows to set the maximum allowable temperature which over rides the primary temperature controller. During each drying experiment, inlet and outlet air temperature, relative humidity was recorded at regular interval of $1 \mathrm{~s}$ using humidity sensor HMP60 make Vaisala. Weight of almonds was also measured intermittently during the drying experiments. 


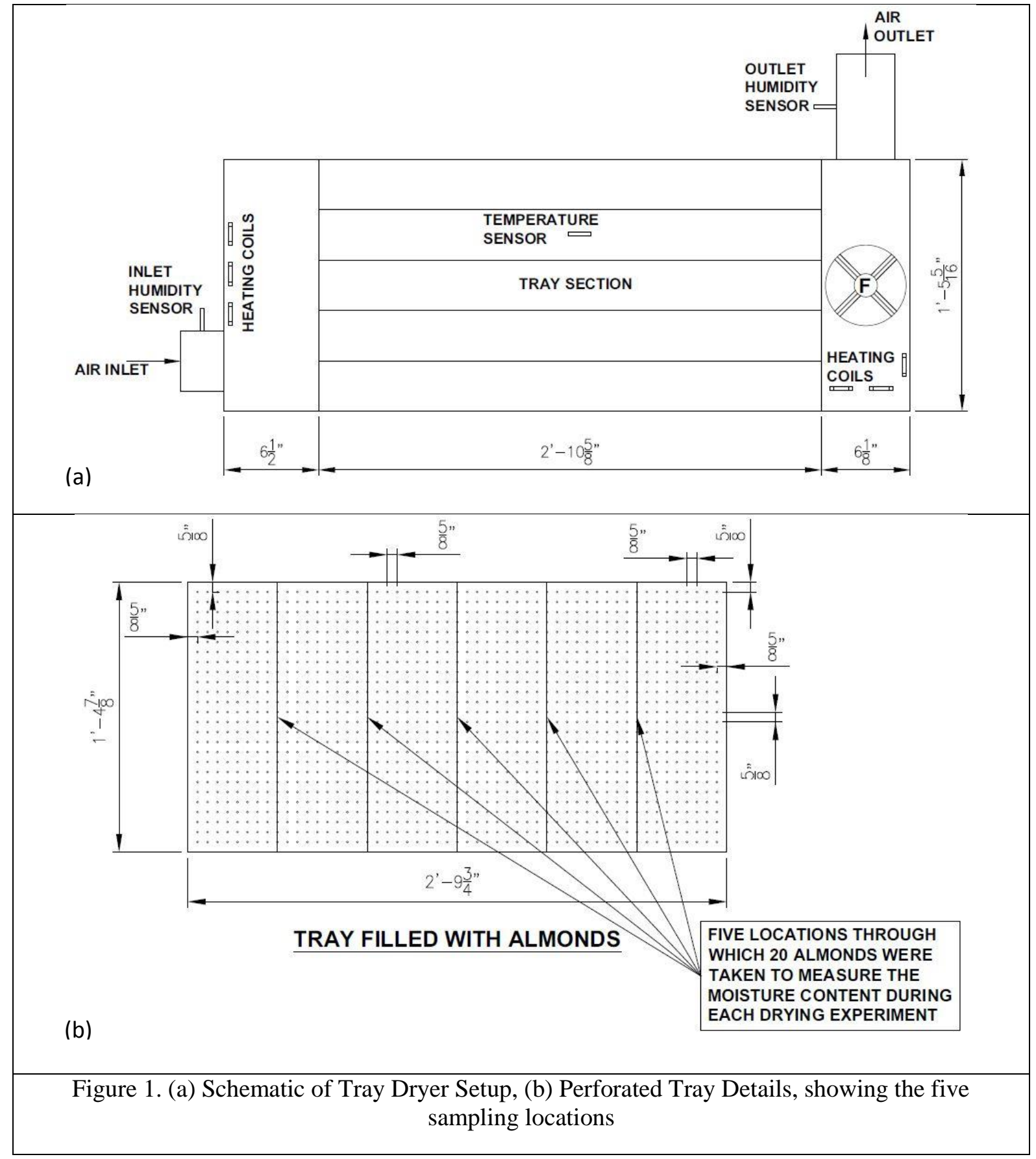

\subsection{Experimental procedure}

Almonds purchased from local market were used to conduct the experiments. The initial moisture content of almonds was found to be $3-4 \%$. All the values of moisture content reported in this work were determined by considering a reference weight of almonds after drying at a temperature of $120{ }^{\circ} \mathrm{C}$ for a period of 8-10 hours as zero moisture content. It is however possible that the reference weight may not be at zero moisture content and actual moisture content in almonds may be little higher than the reported values. Around $2 \mathrm{~kg}$ of almonds were soaked using distilled water for 10 hours. Size of few almonds were randomly measured. The average dimensions were found to be as length: $29 \mathrm{~mm}$, width: $15 \mathrm{~mm}$ and height: $8 \mathrm{~mm}$. Soaked almonds were filled uniformly in a single tray, Figure 2a shows the image of 
the tray filled with soaked almonds. The desired drying temperature was set in the temperature controller, inlet and outlet humidity sensors were installed to record the measurements. The location of temperature sensor (shown in Figure 2a) was in the middle of the tray dryer, based on which temperature set point was determined. The unit was started, with heating coils on and fan circulating ambient air through the unit. Each experiment was carried out in triplicates to quantify the error associated with the measurements. During experiments, samples of almonds were taken from five locations in the tray. Figure $1 \mathrm{~b}$ shows the schematic of tray, pointing the five locations through which 20 almonds were taken during the drying experiment. The door of the unit was opened to take out 20 almonds from each of these five locations. When the door was opened to collect almonds, fresh air enters the unit and flow out through the outlet. Since the ambient air has lower humidity this showed sudden fall in the outlet humidity values. As this phenomenon could not be captured in simulations, the corresponding outlet humidity values during the door opening time were eliminated from the experimental data. Due to this there is a gap in the experimental data during certain intervals of time. Weight of 20 almonds from each location was measured to estimate the moisture content in almonds. Weight measurements of almonds was done at a regular interval of 60 minutes, during each drying experiment. Air mass flow rates was also measured at the outlet section using TESTO-425 Air velocity meter.

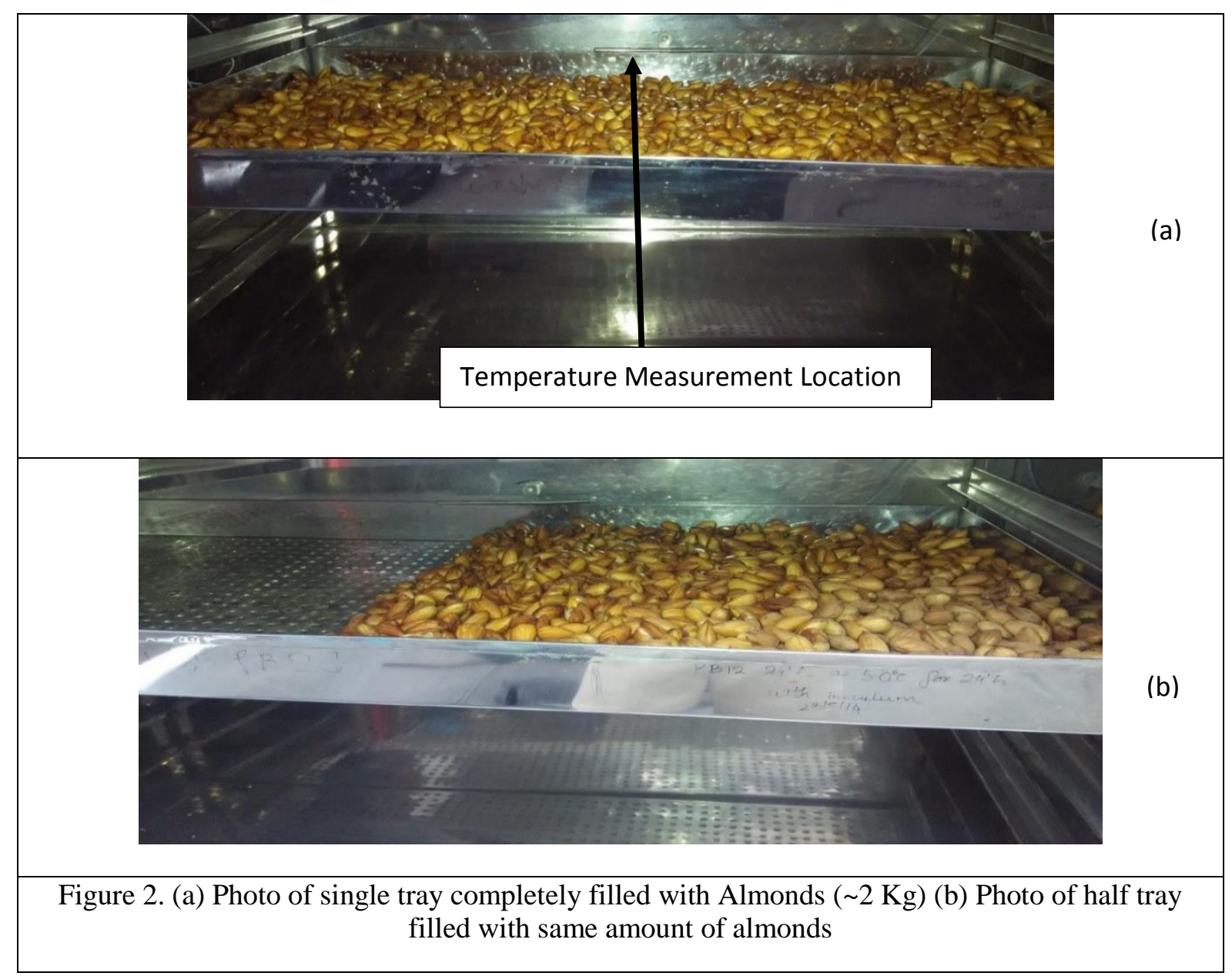


Following experimental data was collected for each drying experiment:

- Inlet and outlet air temperatures and relative humidity

- Average weight of almonds at five locations in the tray, for every 60 minutes of drying time

- Air temperature in the unit

- Mass flow rate of air in the outlet section

Based on the air mass flow rate, and humidity values for inlet and outlet, overall mass balance was checked for the change in moisture content in almonds. The mass balance was close within an error bar of $\pm 10 \%$. Experiments were also conducted where tray was half filled with the same amount of almonds (bed thickness of almonds in a tray is doubled). Experiments were conducted at set temperature of 75 ${ }^{\circ} \mathrm{C}$ to measure the inlet and outlet air humidity along with the change in weight of almonds during the experiment.

\section{Modelling of flow, heat transfer and drying in a tray dryer}

The objective of computational model was to simulate the moisture content and temperature variation in solids (almonds) and air during the complete drying process. The variation of solids moisture and temperature needs to be predicted throughout the tray considering the influence of the surrounding air. It is therefore essential to develop fully coupled model equations for flow, temperature, moisture variation and solids temperature representing processes occurring in a tray dryer which need to be solved simultaneously. Based on our earlier work for single and multiple particles (Chilka and Ranade $\left.{ }^{[9,10]}\right)$ it showed that temperature equilibrium within the almond particle was achieved quickly. Biot number for heat transfer and mass transfer for almonds is 0.17 and 2.1 respectively.

For modelling of bulk drying characteristics, there are certain key parameters which are essential. Like relation of effective diffusivity with respect to temperature. There will be variation of temperature in a large scale drying unit. To capture the corresponding varying drying characteristics, estimation of temperature dependent variables is essential. Experiments and modelling of single almond kernel as described in Chilka and Ranade ${ }^{[9,10]}$ was used to estimate the effective diffusivity at different temperatures. Using the drying data at different temperatures, effective diffusivity as a function of temperature expressed using Arrhenius law was obtained. These parameters for effective diffusivity were used in the modelling of tray drying characteristics. Transport properties that are crucial for drying characteristics are heat and mass transfer coefficients. Experiments and modelling of multiple particles Chilka and Ranade ${ }^{[10]}$ were used to determine the average heat transfer coefficient values for almond kernel, which was extended for modelling of bulk drying characteristics. 


\subsection{Model equations}

Mass, momentum and energy balance equations were formulated along with additional scalar equations to simulate the flow, air temperature, almond moisture and almond temperature distribution in the tray dryer. Following assumptions were used while formulating the model equations: (1) all the walls of the unit were considered as adiabatic, the unit was adequately insulated to prevent any heat loss (2) porous media approach was used to model the flow resistance offered by almonds and perforated plate. Resistance offered by the layer of almonds and perforated plate was considered by providing appropriate sink terms in the momentum balance equations. Appropriate source terms and governing equations were formulated to simulate humidity of air (water vapour uptake from almonds) and moisture content of almonds. Appropriate energy balances were formulated to simulate temperature variation in almonds as well as in air. The model equations are discussed in the following.

\subsubsection{Mass conservation for air:}

$$
\frac{\partial \rho}{\partial t}+\nabla \cdot(\rho \vec{v})=S_{m}
$$

The source $S_{m}$ is added corresponding to the moisture transfer between the almonds and air during drying. $S_{m}$ corresponds to RHS term of Equation (8).

3.1.2 Momentum conservation for air:

$$
\frac{\partial}{\partial t}(\rho \vec{v})+\nabla \cdot(\rho \vec{v} \vec{v})=-\nabla p+\nabla \cdot(\overline{\bar{\tau}})+\vec{F}
$$

where, $p$ is static pressure, $\overline{\bar{\tau}}$ is the stress tensor, and $\vec{F}$, corresponds to the momentum source term due to porous media, corresponding to the layer of almonds.

\subsubsection{Momentum source term:}

As almonds were spread on the tray, the layer of fluid in the tray corresponding to the thickness of almonds bed, will resist fluid flow. Porous media approach was used to model the flow resistance offered by the layer of almonds in the tray. Influence of porous media was modelled by specifying a momentum source term in the standard fluid flow Equation (2) as:

$$
F_{i}=-\left(\frac{\mu}{\alpha} v_{i}+C_{2} \frac{1}{2} \rho|v| v_{i}\right)
$$

Where $\alpha$ is the permeability and $C_{2}$ is the inertial resistance factor. Due to unavailability of the pressure drop data for almonds, the resistance coefficients were estimated using Ergun's equation. Based on Ergun's equation the value of $\alpha$ and $C_{2}$ was calculated using Equations (4) and (5): 


$$
\begin{gathered}
\alpha=\frac{D_{p}^{2}}{150} \frac{\varepsilon^{3}}{(1-\varepsilon)^{2}} \\
C_{2}=\frac{3.5}{D_{p}} \frac{(1-\varepsilon)}{\varepsilon^{3}}
\end{gathered}
$$

where $D_{p}$ is the mean particle diameter and $\varepsilon$ is the void fraction.

As there will be additional source of resistance offered by the perforated plate of tray. The resistance offered by perforated plate was calculated using the equation based on Smith and Van Winkle ${ }^{[18]}$. The value of $C_{2}$ corresponding to perforated plate is calculated as:

$$
C_{2}=\frac{1}{O^{2}} \frac{\left(A_{p} / A_{f}\right)^{2}-1}{L}
$$

where $O$ is an empirically derived constant with a value of $0.98, A_{p}$ is total area of plate (solids and holes), $A_{f}$ is total area of the holes and $L$ is the plate thickness.

\subsubsection{Modelling of turbulent flow:}

The realizable $\mathrm{k}-\varepsilon$ turbulence model was used to capture the turbulence in the air flow within the tray dryer. The governing equations for the same may be found in the user manual of Ansys Fluent ${ }^{[17]}$ and therefore not included here. Based on the fan speed the flow regime was calculated to be turbulent. The considered turbulence model provides adequate results for rotating equipment system. Standard wall functions were used to capture the near wall effects of the flows.

\subsubsection{Modelling of moisture transfer:}

During the drying process as the almonds are being dried, moisture gets transferred from solids to air. This increases the air humidity, which in turns impacts the drying rate. Fully coupled heat and mass transfer simulations are needed to model the change in humidity of air and its influence on the drying of almonds. Species transport model was used to solve for the change in air humidity during the drying process. The species mass fractions in air were simulated by solving the following equation:

$$
\frac{\partial}{\partial t}\left(\rho Y_{i}\right)+\nabla \cdot\left(\rho \vec{v} Y_{i}\right)=-\nabla \cdot \vec{J}_{i}+S_{m}
$$

The source term $S_{m}$ was added which corresponds to the transfer of species between almonds and air. 
3.1.6 Modelling of moisture content of almonds:

The moisture content of almonds was described using a User Defined Scalar (UDS) variable. The following equations were solved to simulate the moisture distribution of almonds:

$$
\frac{\partial \Phi_{k}}{\partial t}-D\left(\frac{\partial^{2} \Phi_{k}}{\partial x_{i}^{2}}\right)=-k_{m} A_{s v}\left(C_{s}-C_{v}\right)
$$

where $\Phi_{k}$ is the scalar variable representing the almond moisture content, $D$ is the effective diffusivity. $A_{s v}$ is ratio of almond surface area to volume. Moisture source term was determined based on the rate of change of moisture content during the drying process. This rate depends on the mass transfer coefficient, $k_{m}$ and the difference between concentrations of water vapour at the outer surface of almonds, $C_{s}$ and in the surrounding air $C_{v}$

\subsubsection{Determination of mass transfer coefficient:}

Based on the single particle work, effective diffusivity of almond kernel was estimated as reported by Chilka and Ranade ${ }^{[9]}$. As for tray drying there could be a temperature variation in the unit, hence diffusivity needs to be estimated at respective air temperatures. Arrhenius equation was used for this purpose (Equation 9) and the corresponding parameters were used from the earlier work on single particle by Chilka and Ranade ${ }^{[9]}$.

$$
D=6.6 \times 10^{-6} \exp \left(-\frac{27371300}{R T}\right)
$$

Mass transfer coefficient was estimated using effective diffusivity, heat transfer coefficient using the classical Chilton - Colburn analogy of thermal and concentration boundary layer based on the expressions given in Kaya et al. ${ }^{[16]}$ :

$$
k_{m}=\phi \frac{h_{p} D}{k} L e^{1 / 3}
$$

$L e$ is Lewis number (ratio of thermal diffusivity to mass diffusivity). Higher the Lewis number faster will be the mass transfer as compared to heat transfer. $\phi$ is the correction factor applied to the heat transfer coefficient $h_{p}$, value obtained from the single and multiple particle study (Chilka and Ranade $\left.{ }^{[10]}\right) . D$ is effective diffusivity estimated using Equation (9), $k$ is almond thermal conductivity. The correction factor was determined based on the simulations to match the experimental measurements of moisture for tray dryer experiment.

\subsubsection{Determination of concentration of water vapour at surface:}

Concentration of water vapour at surface is determined using the sorption isotherm equations. Almonds equilibrium moisture data was provided by Pahlevanzadeh ${ }^{[20]}$, for two set of temperatures i.e. 55 and 
$75^{\circ} \mathrm{C}$. This covers the range of temperatures for which tray drying experiments were carried out for our work. A sorption isotherm equation could be used to calculate the equilibrium moisture content corresponding to the solids moisture content. Easily reversible sorption isotherm proposed by Chung et. al. ${ }^{[21]}$ is utilized in this work. The constants of model were estimated using the equilibrium moisture data.

$$
M_{e}=-\frac{1}{b} \log \left(-\frac{T+c-273}{a} \log r_{h}\right)
$$

$M_{e}$ is the equilibrium moisture content as a function of model constants $a, b$ and $c, r_{h}$ is the air relative humidity at corresponding temperature $T$. Table 1 shows the equilibrium data for almonds, and corresponding model constants $(a, b$ and $c$ ) are listed in Table 2, $T$ is temperature expressed in K. To estimate air relative humidity, $r_{h}$ corresponding to solids moisture content.

$$
r_{h}=\frac{p_{a}}{p_{s a t}}
$$

$p_{a}$ is the vapour pressure and $p_{\text {sat }}$ is the saturation vapour pressure of free water. Antoine equation was used to calculate the saturation vapour pressure as a function of temperature.

$$
p_{\text {sat }}=\exp \left(A-\frac{B}{T+C-273}\right)
$$

Equation constants, $A, B$ and $C$ are listed in Table 3, $T$ is air temperature expressed in $\mathrm{K}$.

As the moisture is being transferred from almonds to surrounding air, corresponding source term for water vapour is added in the species equation, to solve for the variation in air humidity.

Table 1. Equilibrium Moisture content for Almonds at 55 and $75{ }^{\circ} \mathrm{C}$ (Pahlevanzadeh ${ }^{[20]}$ )

\begin{tabular}{|c|c|}
\hline$r_{h}$ (Relative Humidity) & $M_{e}$ (Equilibrium Moisture Content) \\
\hline 0.09 & 0.012736 \\
\hline 0.156 & 0.018742 \\
\hline 0.284 & 0.027057 \\
\hline 0.413 & 0.030303 \\
\hline 0.451 & 0.032389 \\
\hline 0.534 & 0.037184 \\
\hline 0.682 & 0.055612 \\
\hline 0.716 & 0.065448 \\
\hline 0.098 & 0.014153 \\
\hline 0.182 & 0.021055 \\
\hline
\end{tabular}




\begin{tabular}{|c|c|}
\hline 0.2997 & 0.03078 \\
\hline 0.424 & 0.035043 \\
\hline 0.48 & 0.040529 \\
\hline 0.576 & 0.048066 \\
\hline 0.71 & 0.067198 \\
\hline 0.764 & 0.08188 \\
\hline
\end{tabular}

Table 2. Chung-Pfost model constants for Almonds over range of 55 to $75{ }^{\circ} \mathrm{C}$. These constants were calculated using the data from Table 1 and Equation (11).

\begin{tabular}{|c|c|}
\hline a & 101894.146 \\
\hline b & 18.786 \\
\hline c & 55311.825 \\
\hline
\end{tabular}

Table 3. Antoine equation constants for calculating saturation pressure. Model constants were calculated using saturation water vapour pressure data with respect to temperature.

\begin{tabular}{|c|c|}
\hline A & 16.464 \\
\hline B & 3926.105 \\
\hline C & 231.447 \\
\hline
\end{tabular}

3.1.9 Modelling of heating elements of the tray dryer:

$$
\frac{\partial}{\partial t}\left(\rho C_{p a} T_{a}\right)+\nabla \cdot\left(\vec{v} \rho C_{p a} T_{a}\right)=\nabla \cdot\left(k_{e f f} \nabla T_{a}\right)+S_{h}
$$

Energy required for drying was supplied by the heating elements through the circulation of hot air. Based on the rate of drying, corresponding heat sink must be accounted to estimate the temperature change.

$S_{h}$ is the heat sink term corresponding to the evaporation of moisture during the drying process, which was like that given by Thorpe ${ }^{[22]}$.

$$
S_{h}=-\left(\left(h_{v}+C_{p v}\left(T_{a}-T_{p}\right)\right) \rho_{p b} \frac{\partial M}{\partial t}+h_{p} A_{s v}\left(T_{a}-T_{p}\right)\right)
$$

Where $h_{v}$ is the latent heat of vaporization, $h_{p}$ is heat transfer coefficient, $A_{s v}$ is ratio of surface area to volume of almond kernel. $T_{a}$ and $T_{p}$ are air and solids temperature respectively, $C_{p v}$ is the specific heat of water vapour. $\rho_{p b}$ is bulk density of particle. Latent heat of vaporization, $h_{v}(\mathrm{~J} / \mathrm{kg})$ was considered as:

$$
h_{v}=2500800-2366\left(T_{a}-273.15\right)
$$




\subsubsection{Almonds temperature variation:}

Additional User Defined Scalar (UDS) equation was solved to simulate the variation of almond temperature during the drying process. The UDS equation for almond temperature is:

$$
\begin{gathered}
\frac{\partial\left(T_{p}\right)}{\partial t}-\frac{k}{\rho_{p b} C_{p s}}\left(\frac{\partial^{2} T_{p}}{\partial x_{i}^{2}}\right)=S_{h p} \\
S_{h p}=\frac{h_{p} A_{s v}\left(T_{a}-T_{p}\right)}{\rho_{p b} C_{p s}}
\end{gathered}
$$

Appropriate boundary conditions are needed to solve these model equations. For avoiding influence of domain boundary on inlet flow, a spherical domain was used at the inlet to model the flow entering the unit from atmosphere. Initially an attempt was made to simulate air flow generated by fan. Moving Reference Frame (MRF) approach given by Luo et al. ${ }^{[19]}$ was used to model the air flow generated by the fan in the tray dryer. Fan blade geometry was explicitly modelled in the CFD model, Figure 3 shows the detail geometry of the fan considered for simulations. However, though the predicted air mass flow rate using the MRF approach was close to the experimentally measured value of air mass flow rate, we decided to specify experimentally measured air mass flow rate to eliminate any possible errors due to the difference in the air flow rate. For all subsequent simulations, mass flow inlet type boundary condition was specified for the air inlet using the measured flow rate of air. Pressure outlet boundary type was used for the outlet of the unit.

The unit has six U-shaped heating elements, each of 500 Watt. Initially simulations were performed using heat flux boundary condition on the heating coil surface. During the simulation, it was observed that certain cells reach unrealistically high temperatures which lead to convergence issues. To improve convergence behaviour, simulations were performed by specifying temperature on heating coil surface. During the experiments air temperature within the tray dryer unit was measured at a specific location shown in Figure 2 (a). As the set temperature was constant, the measured air temperature also reached a constant value during the drying experiments. In simulations air temperature at the same location in the tray dryer unit was monitored. The surface temperature on heating elements was changed to monitor the corresponding air temperature in the unit. The heating coil temperature was set such that air temperature predicted by simulations is close to the measured value.

\subsection{Solution of model equations}

All the above equations need to be implemented appropriately in CFD frame work, which will allow for simultaneous solutions for flow, heat transfer, moisture and temperature variation for almonds. Simulations were carried out using CFD Solver ANSYS Fluent release version 14.5. It was necessary to use the user defined functionality of Ansys Fluent ${ }^{[17]}$ solver for solving additional scalar equations 
presented in Section 3.1. The details of the developed user defined functions are described in the following sub-section.

\subsubsection{Development of User Defined Functions (UDF's):}

Ansys Fluent ${ }^{[17]}$ provides suitable macros which could be utilized to develop UDF's to implement the above equations. UDF's were used for following, during the simulation process:

- To provide the unsteady terms for UDS's equation of almond temperature and almond moisture.

- To calculate the source terms for almond moisture and temperature equations.

- To calculate the source terms for air humidity and temperature equations.

The details of the macros used, and their application are listed in Table 4.

Table 4. Details of macros used in UDF

\begin{tabular}{|l|l|}
\hline Macro & Application \\
\hline $\begin{array}{l}\text { DEFINE_UDS_UNSTEADY(uds0, } \\
\text { temperature, d) }\end{array}$ & $\begin{array}{l}\text { Updating the unsteady term of UDS-0 equation for } \\
\text { almond temperature Equation (17) at each time } \\
\text { step }\end{array}$ \\
\hline $\begin{array}{l}\text { DEFINE_UDS_UNSTEADY(uds1,m } \\
\text { oisture, d) }\end{array}$ & $\begin{array}{l}\text { Updating the unsteady term of UDS-1 equation for } \\
\text { almond moisture Equation (8) at each time step }\end{array}$ \\
\hline $\begin{array}{l}\text { DEFINE_SOURCE(almond_moistur } \\
\text { e, d) }\end{array}$ & $\begin{array}{l}\text { Calculating the moisture source term and returning } \\
\text { it to the solver }\end{array}$ \\
\hline $\begin{array}{l}\text { DEFINE_SOURCE(almond_tempera } \\
\text { ture,d) }\end{array}$ & $\begin{array}{l}\text { Calculating the energy source term Equation (18) } \\
\text { and returning it to the solver }\end{array}$ \\
\hline DEFINE_SOURCE(vapor_source, d) & $\begin{array}{l}\text { Specifying the corresponding moisture Equation } \\
\text { (8) source for updating the air humidity }\end{array}$ \\
\hline $\begin{array}{l}\text { DEFINE_SOURCE(energy_source, } \\
\text { d) }\end{array}$ & $\begin{array}{l}\text { Calculating the energy sink term for air } \\
\text { temperature Equation (15) and returning to the } \\
\text { solver }\end{array}$ \\
\hline Flow variable macros C_P(c,t) & Returning cell pressure (Pa) \\
\hline C_YI(c,t,i) & Returning cell mass fraction of ith species \\
\hline C_T(c,t) & Returning cell temperature (K) \\
\hline $\begin{array}{l}\text { User-defined scalar and memory } \\
\text { macros C_UDSI(c,t,i) }\end{array}$ & Accessing to the value of ith user-defined scalar \\
\hline C_UDMI(c,t,i) & Accessing to the value of ith user-defined memory \\
\hline Geometry macros C_VOLUME(c,t) & Accessing to the value of cell volume (m ${ }^{3}$ ) \\
\hline $\begin{array}{l}\text { Time macros } \\
\text { RP_Get_Real(“physical-time-step”) }\end{array}$ & Returning current time step size (s) \\
\hline
\end{tabular}

\subsubsection{Geometry, meshing and simulation set-up details}

Figure 3 ( $a$ and $b$ ) shows the 3D model of the dryer which was used for simulations and some details of generated mesh. All the major components were considered i.e., heating elements, single tray, fan, air inlet and outlet ducts. To generate the computational mesh for simulations GAMBIT grid generator (ANSYS Inc.) was used. Fine mesh size was used around the fan blades to capture the flow generated 
in the tray dryer unit accurately. As standard wall functions were used in the simulation y+ values for wall were maintained in the range of 30-60. The porous zone corresponding to almonds was meshed such that multiple cells represent single almond layer. Combination of hexahedral and tetrahedral elements were used to generate the mesh for the complete unit, and the surrounding air domain. To obtain grid independent solution three different sizes of mesh was generated. Velocities and temperatures at few locations in the tray dryer unit were monitored and compared for results from different mesh sizes. Based on this comparison of results from different mesh size the total mesh count of about 4.5 million cells for a tray dryer was found to be almost grid independent. Second order discretization scheme was used for pressure, momentum, energy, species and UDS equations. SIMPLE algorithm was used for pressure-velocity coupling. Iterations were carried out till the residuals for all equations were below $1 \times 10^{-4}$. Adequate care was taken to ensure that numerical aspects (number of computational cells, discretization schemes, convergence criteria) do not influence simulated results (Ranade ${ }^{[23]}$ ). Developed DEFINE macros were hooked at appropriate locations in the model for UDS and specifying source terms for fluid zones. The value of correction factor, $\phi$ in Equation (10) was set to 1.5 for all simulations.

\section{Results and Discussion}

\subsection{Flow, temperature and moisture distribution within tray dryer unit}

Using the detailed geometry and mesh for the tray dryer unit simulations for flow, heat transfer and moisture transport were carried out. The results for the simulation corresponding to set temperature of $55^{\circ} \mathrm{C}$ are discussed here. Simulated velocity and temperature distribution are shown in Figures $4 \mathrm{a}$ and $4 \mathrm{~b}$ respectively. As the inlet location is at the bottom of the unit, higher air flow velocity exists in the bottom section of the unit. In this simulation a single tray placed in the middle of the unit was considered. The air entering the dryer was heated by the coils provided in the dryer. Temperature boundary condition was specified for the heating coils to model the heat source supplied for drying. Based on preliminary numerical experiments, a temperature of $177^{\circ} \mathrm{C}$ was specified at the coil surface which showed good agreement with the temperature of air at the measurement location $\left(54{ }^{\circ} \mathrm{C}\right)$. Simulated temperature distribution is shown in Figure $4 \mathrm{~b}$. Cold fresh air enters in the bottom section of the unit and therefore relatively lower temperature exists in the bottom region of the unit as compared to the top region. Higher temperature exists around the coils and reasonably uniform temperature was achieved around the tray in the unit. 


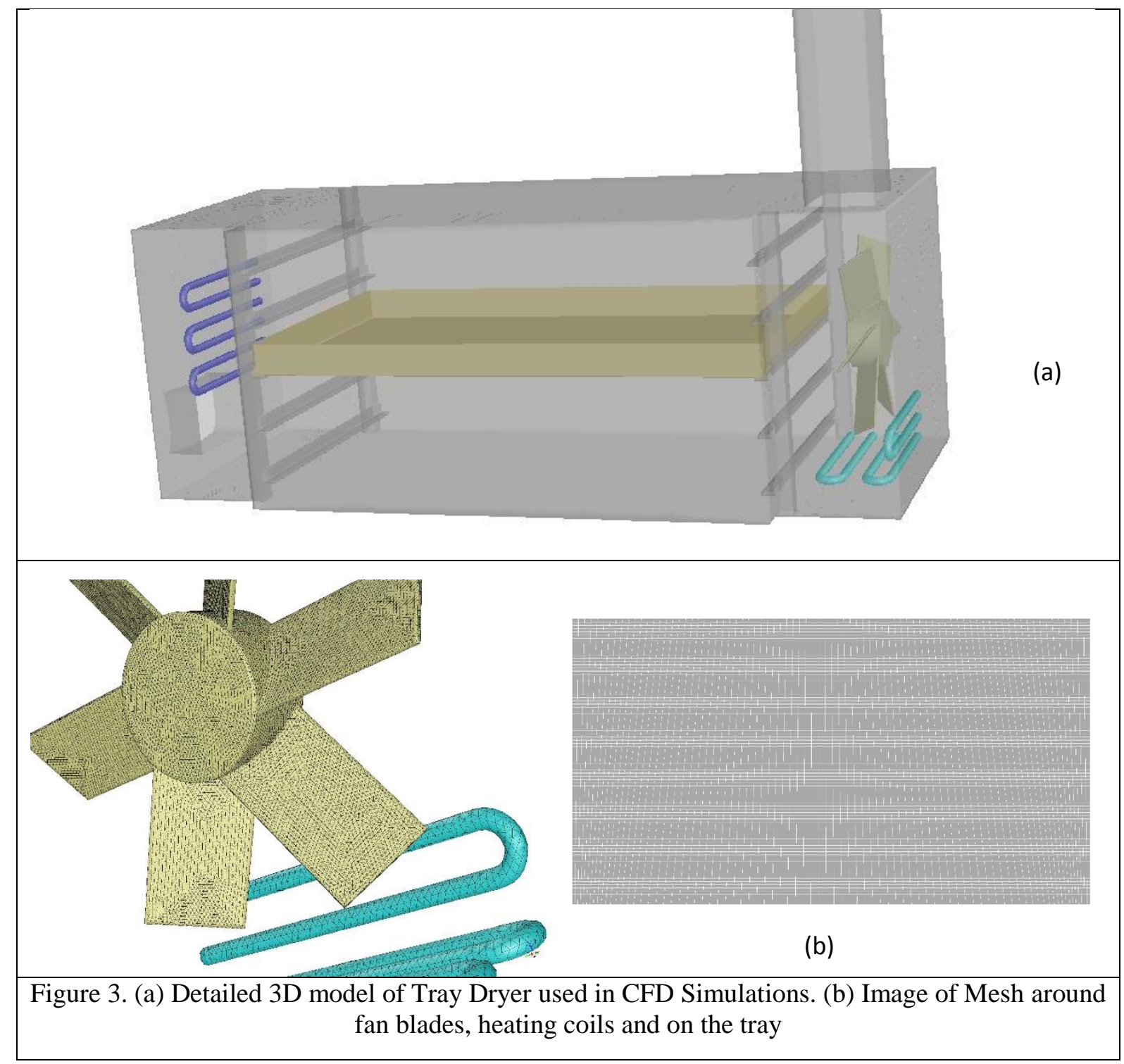

Figure $5 \mathrm{a}$ and $5 \mathrm{~b}$ shows the velocity vectors for air flow within the tray section on a horizontal and vertical plane respectively. As the air flow was flowing through the bottom section of the tray a relatively high velocity exists in the inlet section. Velocity vectors show the flow profile within the tray. Figure $6 \mathrm{a}$ and $6 \mathrm{~b}$ shows the air humidity within the tray during the drying process on horizontal and vertical planes respectively. It shows that air humidity increases as we move in the tray from inlet towards the outlet.

Simulated moisture distribution is shown in Figures $7 \mathrm{a}$ and $7 \mathrm{~b}$ at drying time corresponding to 2 and 7 hours respectively. For 2 hour moisture contours most of the region on tray has high moisture values, except few regions at the two ends of the tray. The regions near heating coils and higher air velocity show lower moisture content. There is a considerable change in the moisture distribution from 2 hours to 7 hours of drying time. Most of the region on tray dryer has uniform moisture content, with a small region of high moisture content on the sides. At the inlet section of the tray there exists a high velocity 
region which leads to faster drying of almonds and lower relative moisture content. Comparing the moisture contours at two different drying times i.e. 2 and 7 hours it shows that moisture content decreases throughout the tray section with increase in drying time. It could also be noticed that the variation in almond moisture content decreases with increase in drying time.

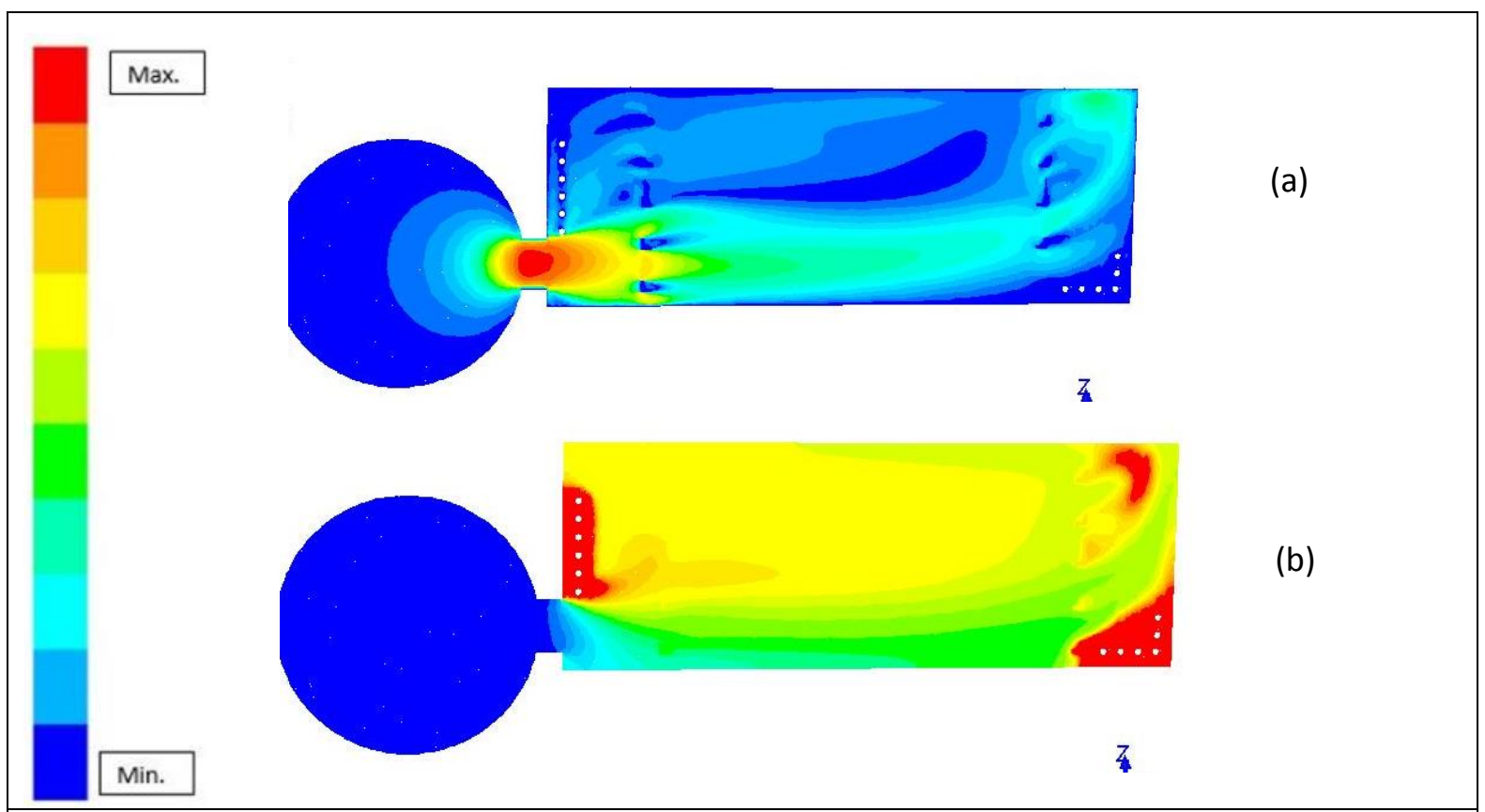

Figure 4. (a) Velocity contours on a vertical plane in the tray dryer unit (Min=0, Max $=0.17 \mathrm{~m} / \mathrm{s}$ ), (b) Temperature distribution on a vertical plane in the tray dryer unit (Min= $300 \mathrm{~K}, \mathrm{Max}=350 \mathrm{~K}$ )

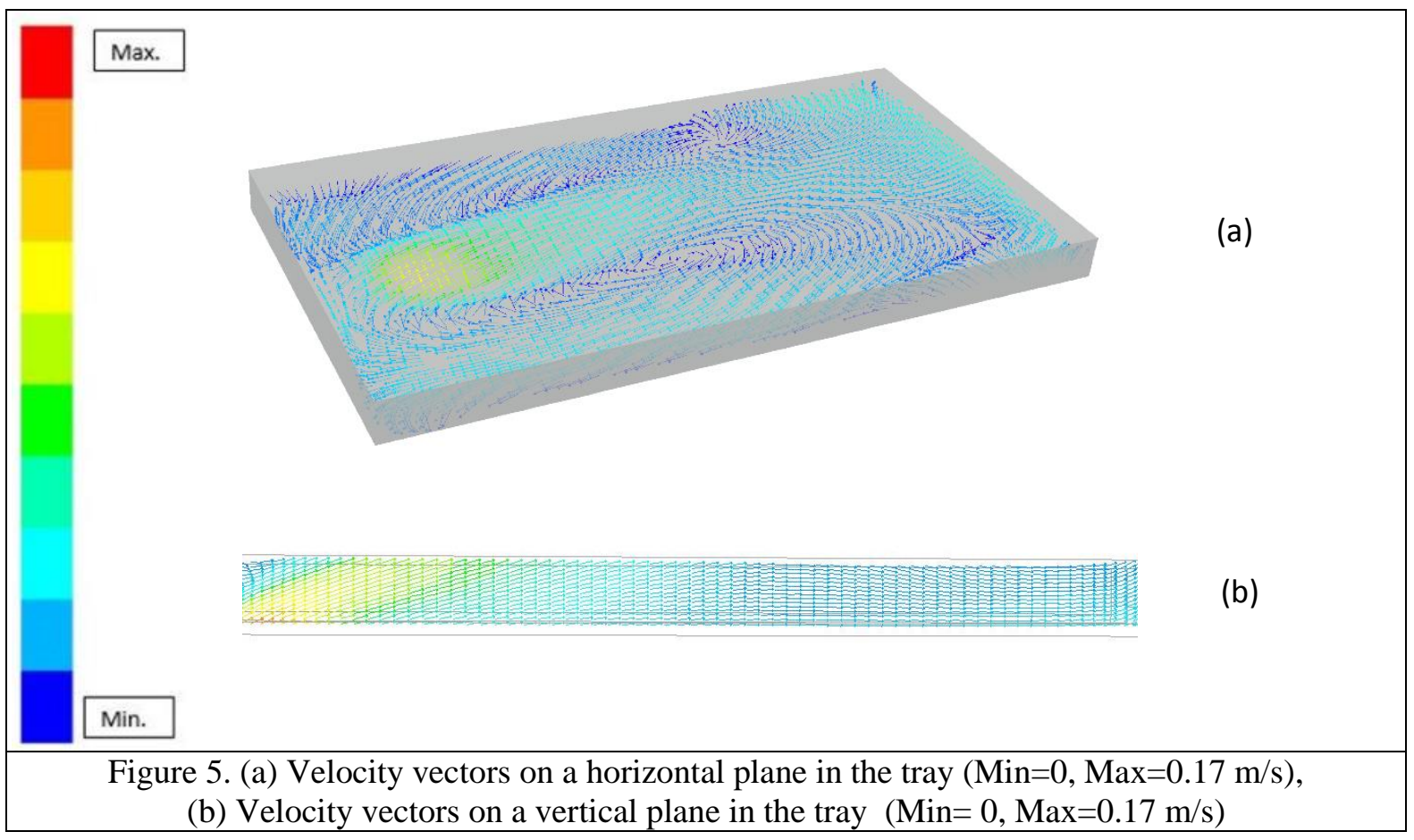




\subsubsection{Comparison with experimental data for $55^{\circ} \mathrm{C}$ case}

Air temperature and relative humidity at inlet and outlet of the unit were recorded continuously during the experiments. Figure 8 shows the variation of air specific humidity at inlet and outlet for set temperature of $55^{\circ} \mathrm{C}$. As the ambient conditions were constant during the drying experiment, inlet air specific humidity was almost constant. For outlet air, it shows a high peak during the initial period of drying, this corresponds to the removal of un-bound moisture from almond surface during the initial phase of drying. This in turn was reflected in high peak in the outlet air humidity measurements. As the drying rate of almonds decreases with time, outlet air humidity also decreases. At the end of the drying time, outlet air humidity becomes almost constant, as there is no further measurable change in the almonds moisture content.

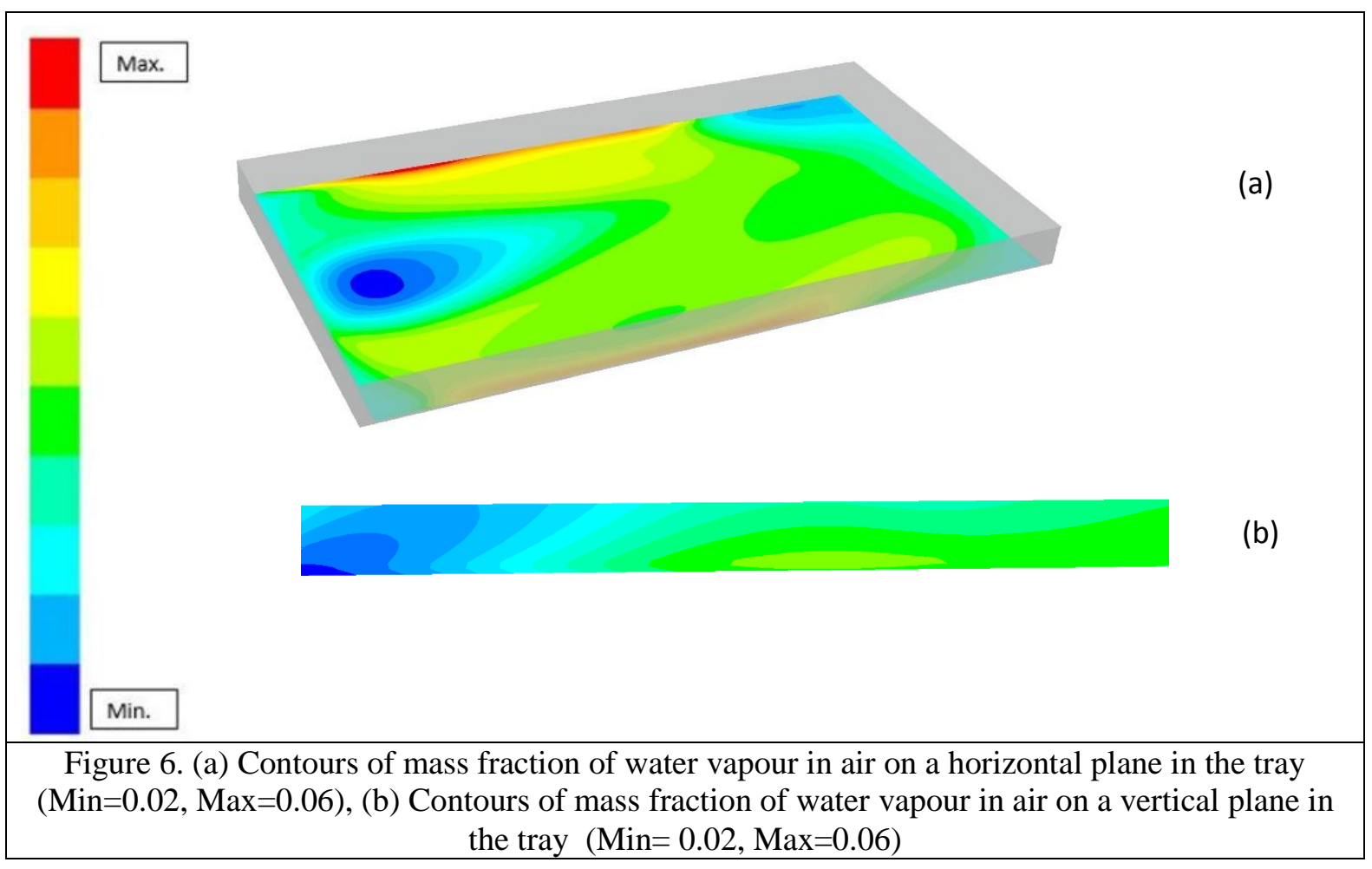

The comparison of the outlet air humidity values simulated using the CFD model and measured from the experiments is shown in Figure 8. There is an under prediction of outlet air humidity values to some extent during the initial phase of drying. At the start there is removal of unbound moisture which happens in a short span of time during the initial drying period, this phenomenon is under predicted. The values for the later period of drying are predicted well by the CFD simulations. The drying model captures the moisture transfer from almonds to air, which enables to predict the increase in specific humidity of air during the drying process. 

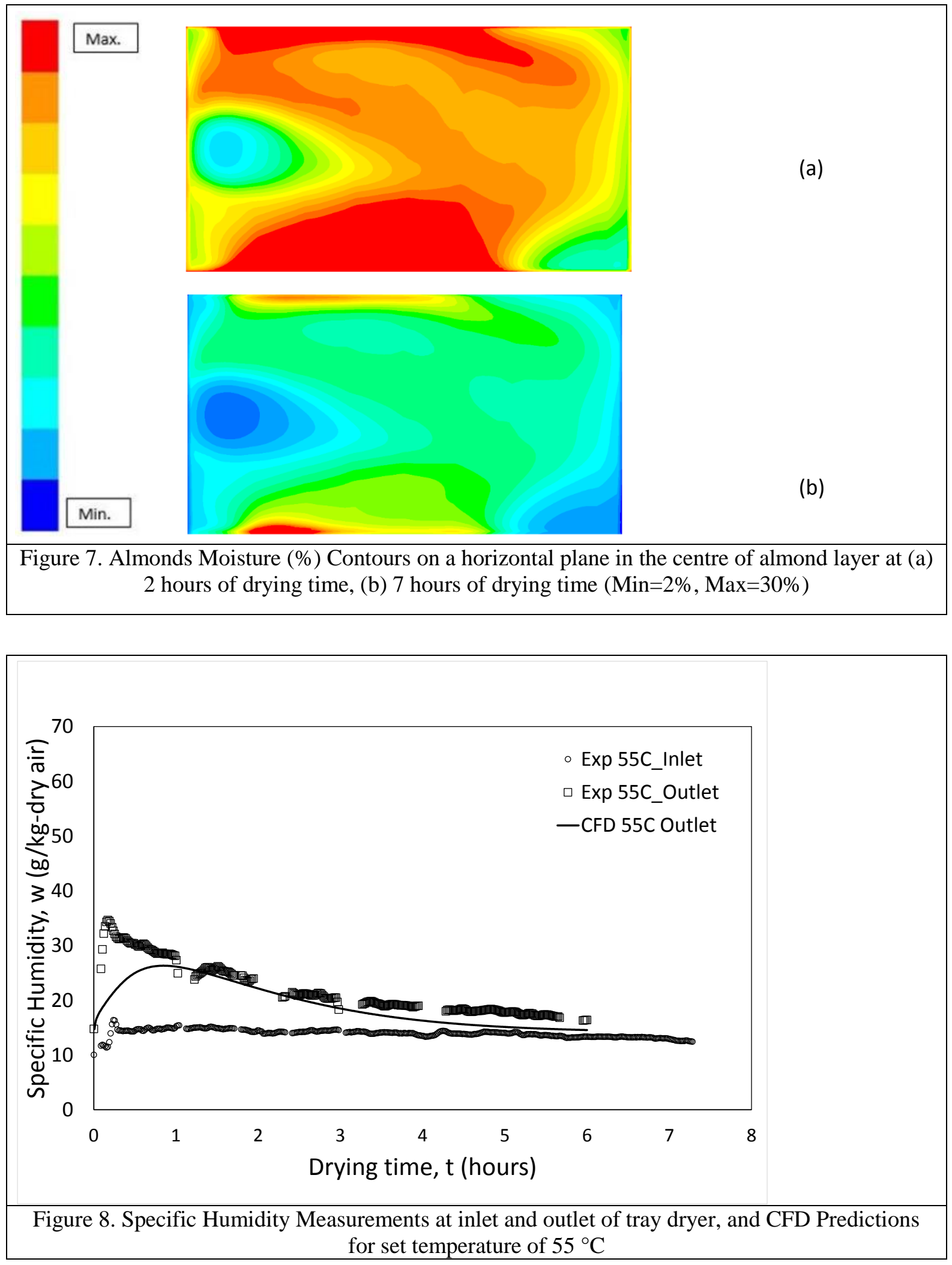

\subsubsection{Influence of air temperature}

Figure 9 shows the comparison of outlet air specific humidity corresponding to three set temperatures. It can be observed that the peak value of outlet air specific humidity increases with increase in air temperature. Initial drying rate is directly proportional to the air temperature which leads to higher 
amount of moisture removal from almonds. As most of the moisture was removed during the first hour of drying, later there was a steep fall in the outlet air humidity for set temperature of $75{ }^{\circ} \mathrm{C}$. This corresponds to the reduction in drying rate. During the later phase of drying the value of outlet air humidity for $75^{\circ} \mathrm{C}$ was lower than as compared to that of $65^{\circ} \mathrm{C}$, however higher than $55^{\circ} \mathrm{C}$. This means that having higher air temperature will not ensure higher drying rate at all stages of drying. It could also be observed that the outlet air humidity attains constant value much earlier for $75{ }^{\circ} \mathrm{C}$ as compared to that of 65 and $55{ }^{\circ} \mathrm{C}$. The outlet air humidity was constant after 5, 6 and 7 hours of drying time for set temperatures of 75,65 and $55{ }^{\circ} \mathrm{C}$ respectively.

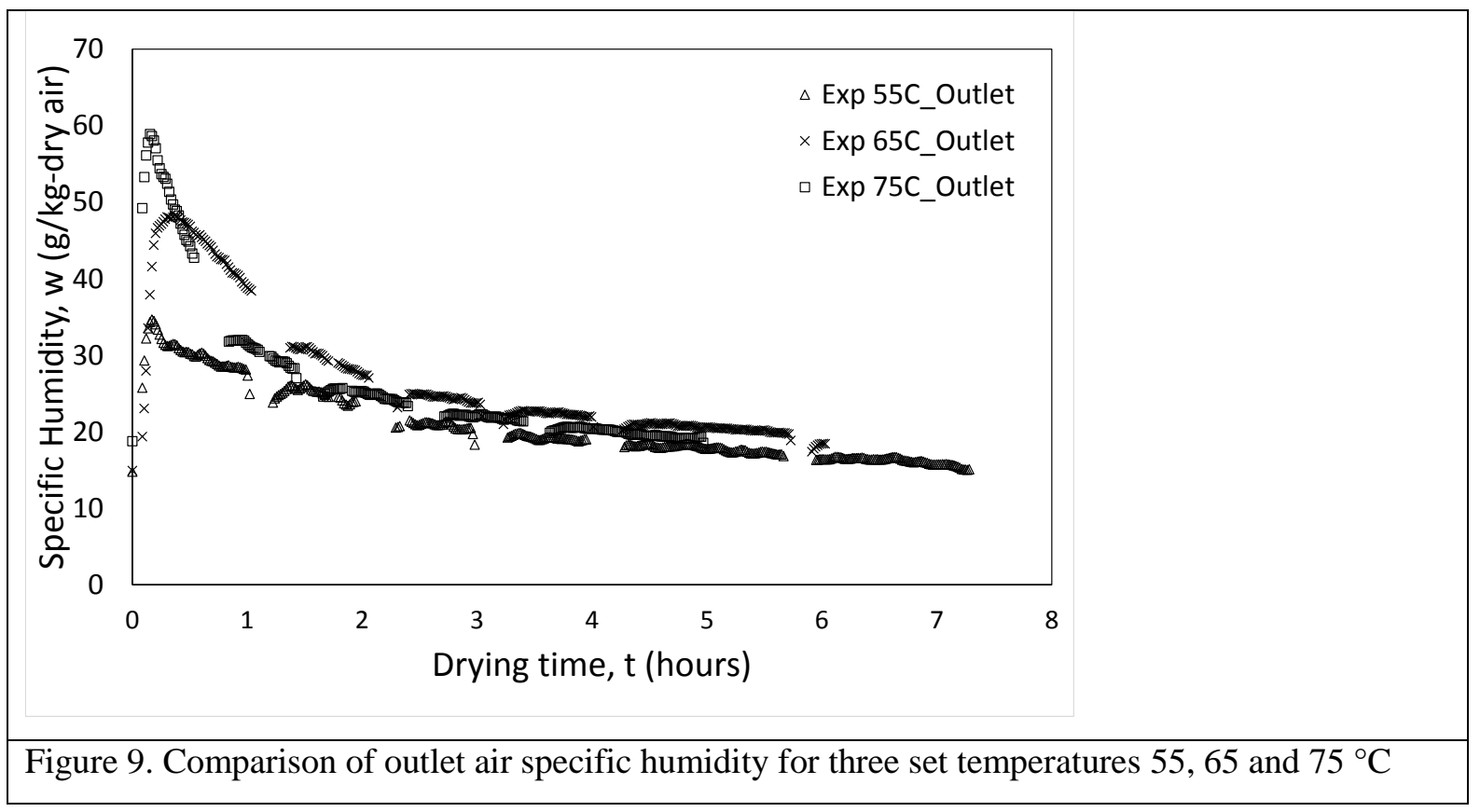

Figure 10a shows the average moisture of almonds measured at five locations in the tray at an interval of 1 hour for set temperature of $55{ }^{\circ} \mathrm{C}$. During the initial course of drying, there was a variation in average almonds moisture across all the five locations. Almonds at either end dry faster due to the vicinity of heating coils, and the almonds in the centre dry relatively slow. Figure 10b shows the variation of moisture at five locations for a drying time of 2 hours. As the drying time progresses, the difference between the almonds moisture content across all the five locations also reduces.

The comparison of simulated average almond moisture content during the drying process and experimental data is shown in Figure 10a. Volume average of almond moisture for fluid zone corresponding to almonds was used to estimate the average almond moisture. Average value of almond moisture predicted from CFD simulations matches well with the experimental measured values with respect to drying time. Both the comparison of outlet air humidity and average moisture content during the drying process matches reasonably well. The model was then used to quantify influence of nonuniform distribution of almonds on tray. 


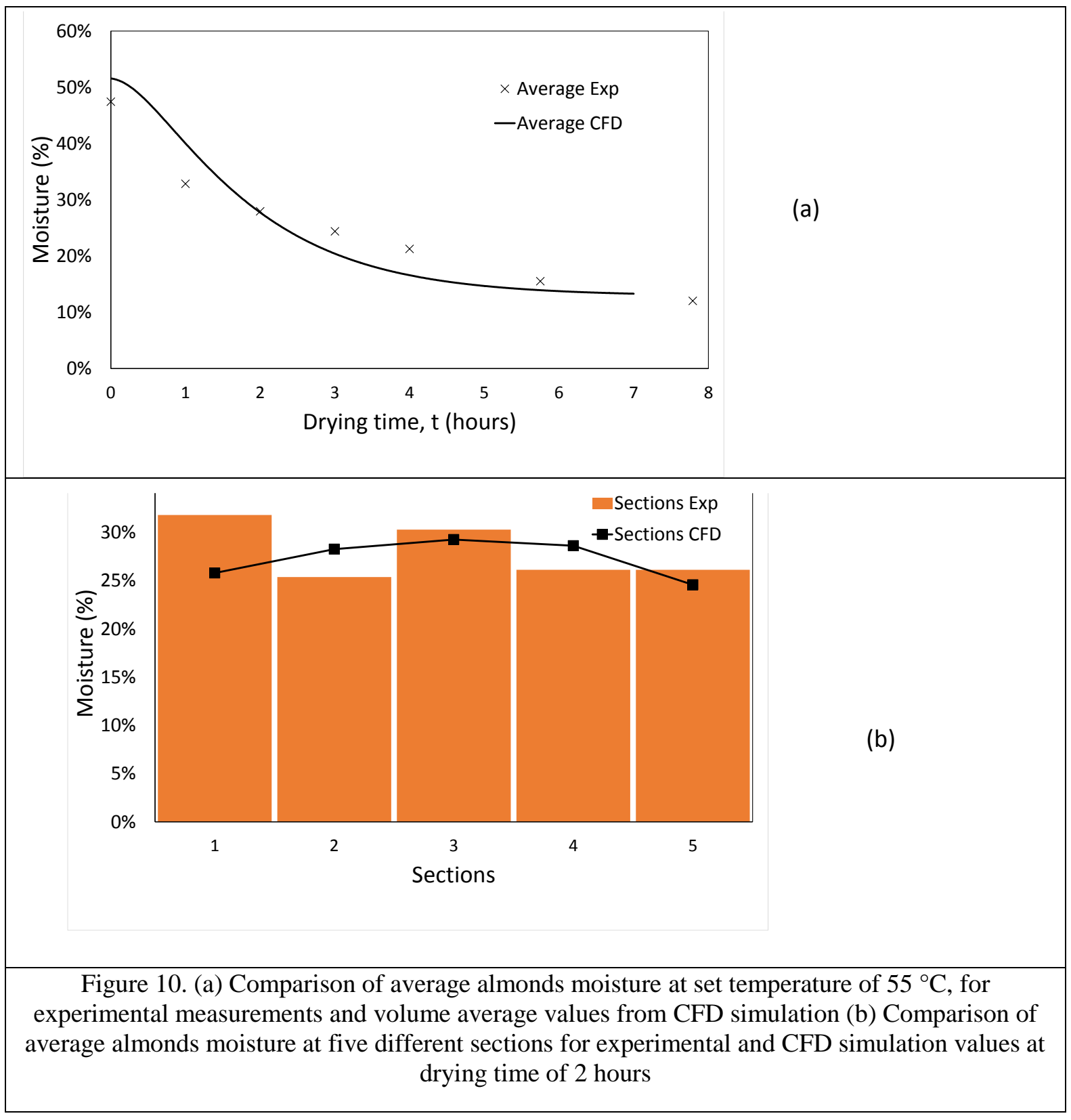

\subsubsection{Influence of non-uniform filling in tray}

In this section results for half-filled tray are discussed. Figure $2 b$ shows the almonds for half-filled tray case. As same amount of almonds were used, bed height of almonds in the tray was almost doubled. The objective of these simulations was to understand the drying behaviour for multiple layers and capture the influence of flow pattern on the drying of almonds. Based on the results from earlier simulation air temperature was reasonably uniform around the tray section. To avoid setting the coil temperature based on multiple trial simulations, air inlet temperature was specified same as the set temperature. Relative humidity of air was measured at inlet and outlet locations of the tray dryer unit. The results are shown in Figure 11 in terms of the outlet air specific humidity variation during experiment. Due to multiple layers of almonds, there was decrease in the rate of moisture loss even as compared to that of full tray. In the earlier study of multiple particle system, it was observed that with 
increase in number of layers the overall average heat and mass transfer coefficients were lower as compared to that of single particle. The trend of outlet air specific humidity was like that of full tray experiments, with higher humidity values during initial phase of drying. After first hour of drying, the rate of change in outlet specific humidity decreases considerably. In the same figure the outlet air specific humidity for fully and half-filled tray is compared. During the initial first hour, drying of halffilled tray was much slower than the fully filled tray. During the later period as well drying of fully filled tray was faster than the half-filled tray configuration.

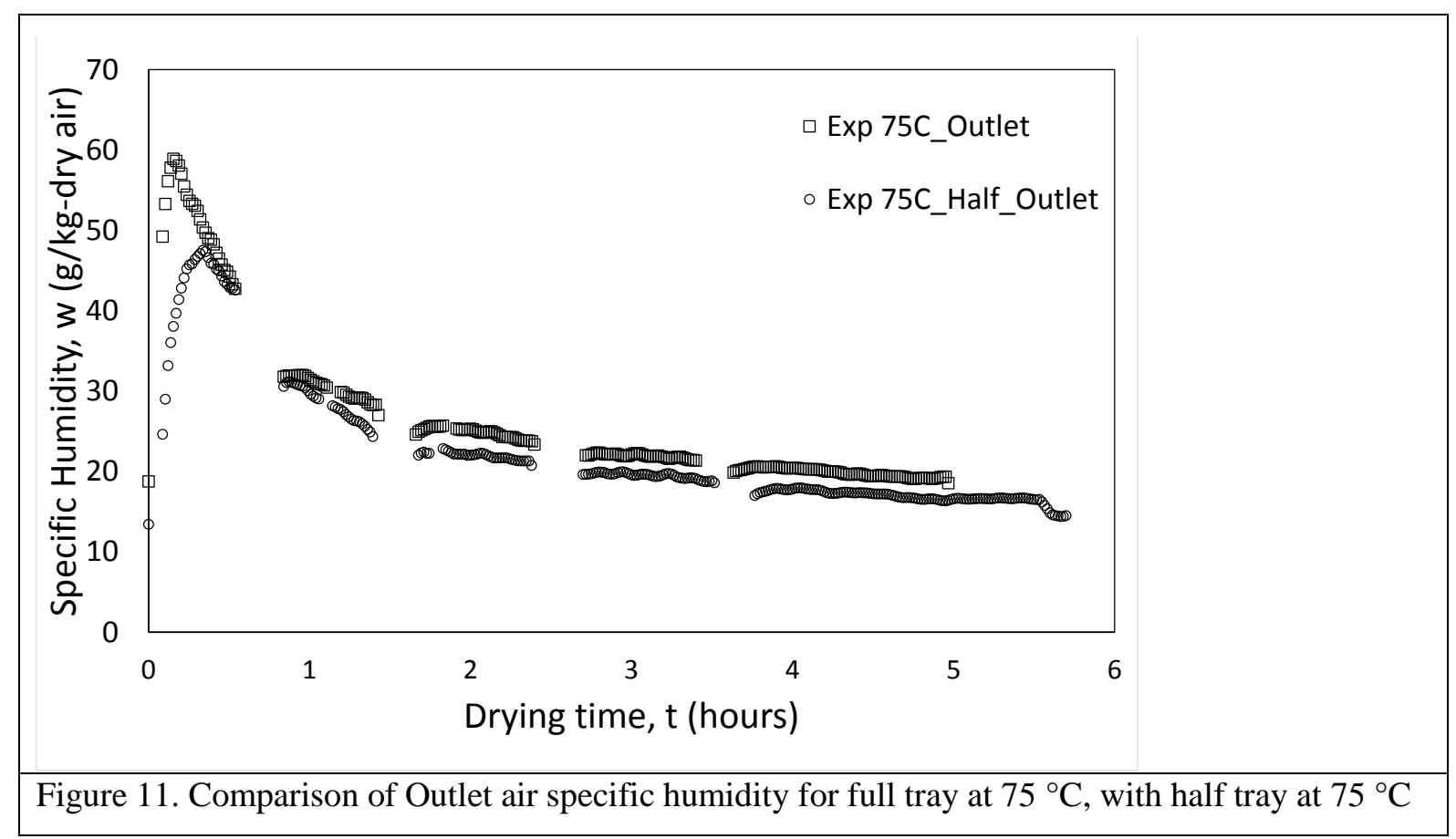

The comparison of the measured and simulated values of volume average almond moisture content for the full tray are shown in Figure 12a. Measurements at five different locations in the tray for half-filled case were measured during the drying process. Average of these moisture values was taken to estimate the total average moisture in the tray during the drying process. From CFD simulations, volume average almond moisture was monitored during the drying process. For this case as well, it could be seen that the CFD predictions agree well with the experimental data. Comparison of the spatial variation of moisture content over the five regions across the tray is shown in Figure $12 \mathrm{~b}$ at a drying time of $1 \mathrm{hr}$. The distribution of velocity and moisture content of almonds on a plane passing through the centre of almonds section for full and half-filled tray is shown in Figures 13a and 13b respectively. The high velocity spot appearing in the contours of velocity indicates the inlet region. For the half-filled tray, the velocity in the empty region is higher as compared to the full tray case. The air temperature was higher for half-filled tray as compared to the full tray, this influences the variation in the almond moisture. It can be seen from Figure 13b that that the variation in almond moisture content for half-filled tray is lower as compared to the full tray results. 


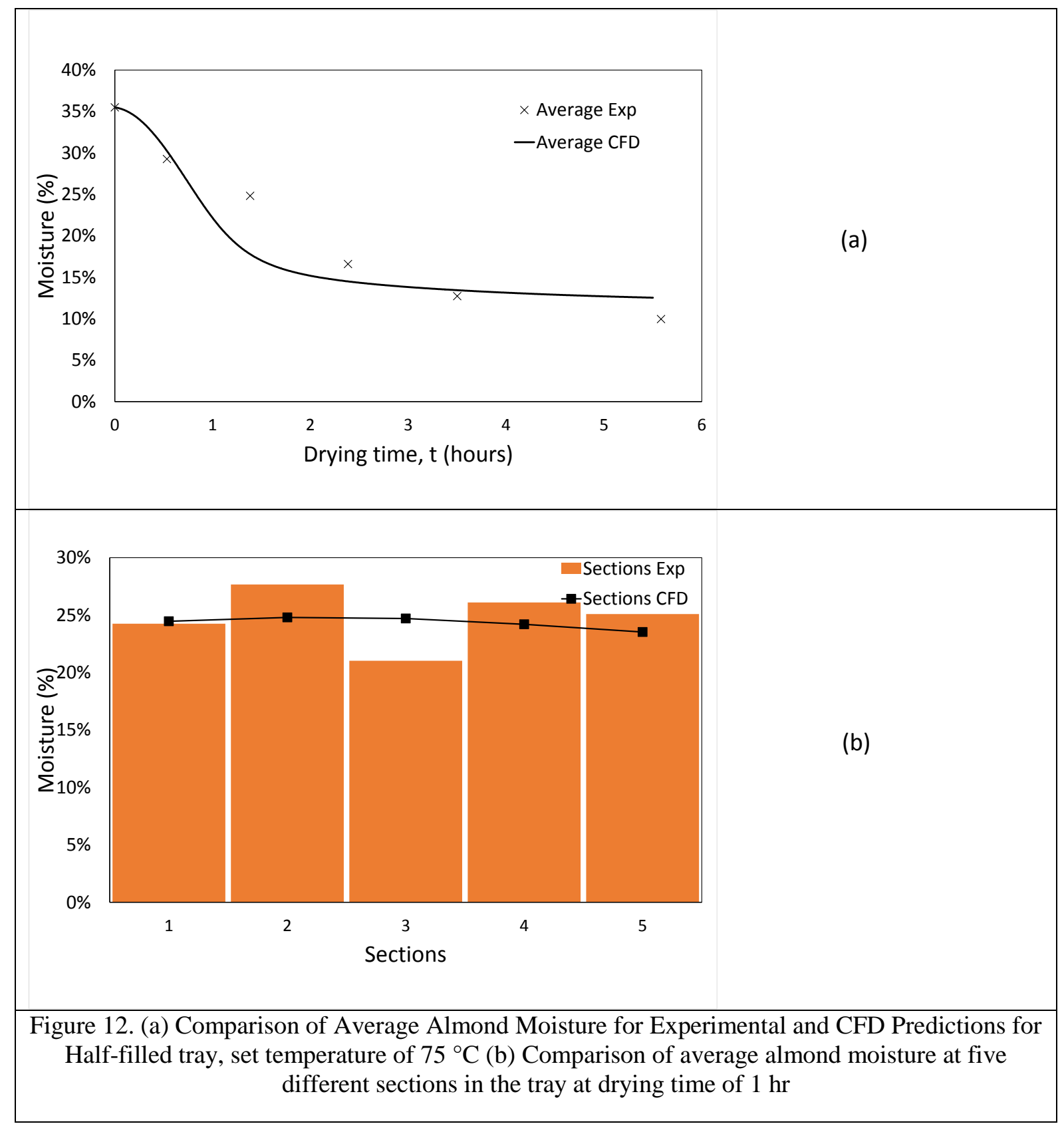

Applicability of developed drying model has been shown for varying almonds configuration and drying temperatures. Performing experiments for every design of dryer is practically not viable. Availability of validated drying models facilitates quantitative understanding of influence of various design (scale, configuration) and operating parameters (air flow rate, air temperature and inlet air humidity) on drying characteristics. This was illustrated by applying the developed model for simulating larger tray dryers. 


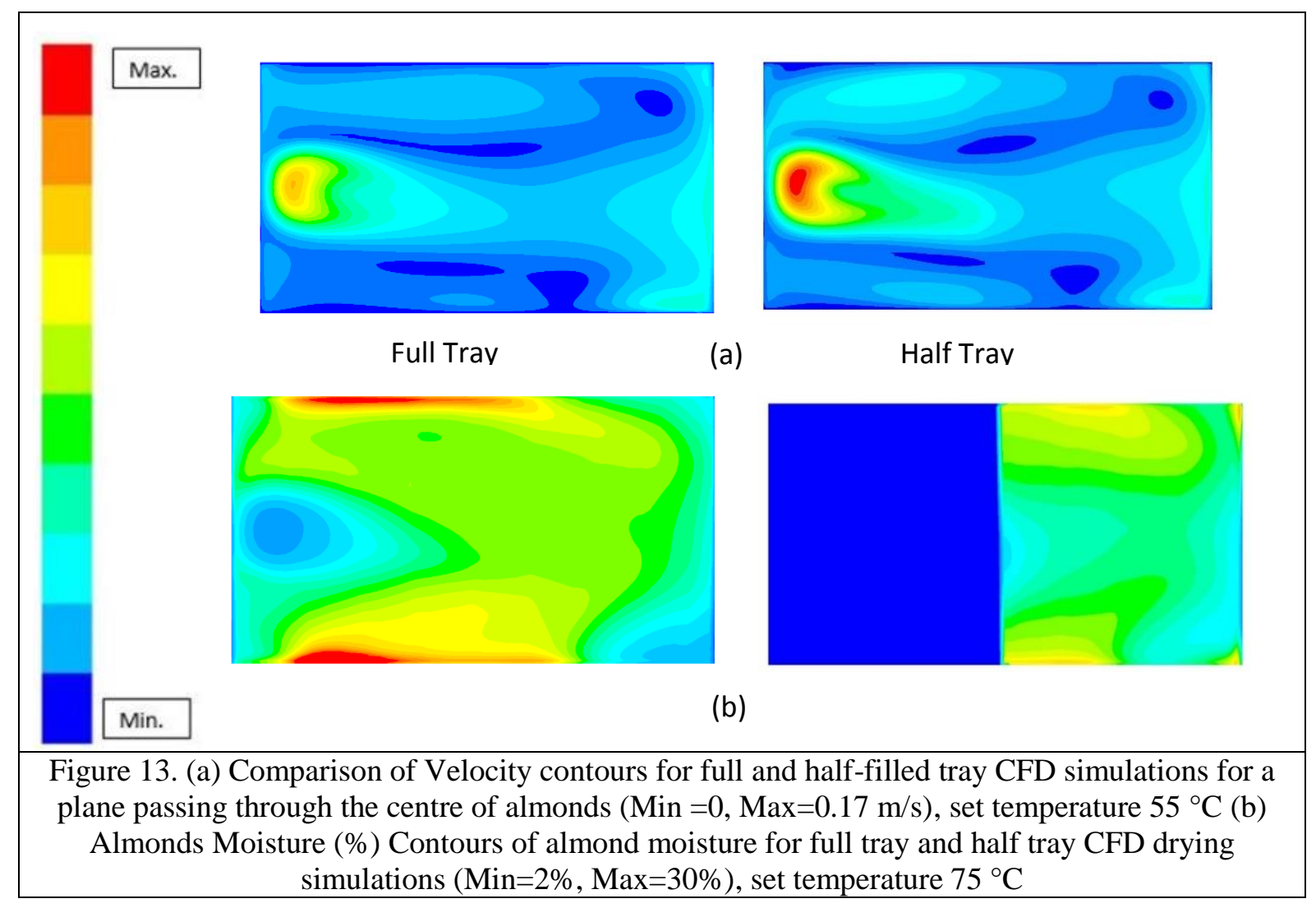

\subsection{Computational Results for a large-scale tray dryer unit}

The CFD model presented earlier was used to carry out few additional simulations for a four times larger tray dryer (by increasing the size of the tray dryer unit by a factor of two in each direction). A simulation was carried out considering only one tray filled with almonds. In this simulation the amount of almonds were four times as compared to the simulations of a smaller dryer with a single tray. Another simulation was carried out with a larger tray dryer geometry with almonds filled in four trays instead of a single tray. This case comprises sixteen times the quantity of almonds as compared to the simulations for a smaller dryer with a single tray. The air flow rate for these simulations was scaled to keep the ratio of air flow rate to the weight of almonds constant. In order to maintain common basis of comparison, air flow rate was scaled based on the amount of almonds. By scaling the unit and adding more number of trays will increase the amount of almonds. Drying simulations were carried out for drying time of 8 hours.

Figure $14 \mathrm{a}$ and $14 \mathrm{~b}$ shows the contours of velocity and air temperature on a horizontal plane in the tray section for larger tray dryer unit respectively. Figure 15a and 15b shows the air humidity and almond moisture content on the horizontal plane for the drying time corresponding to 8 hours respectively. It shows that for the region having lower air temperature results in lower drying rate and higher almond moisture content. 


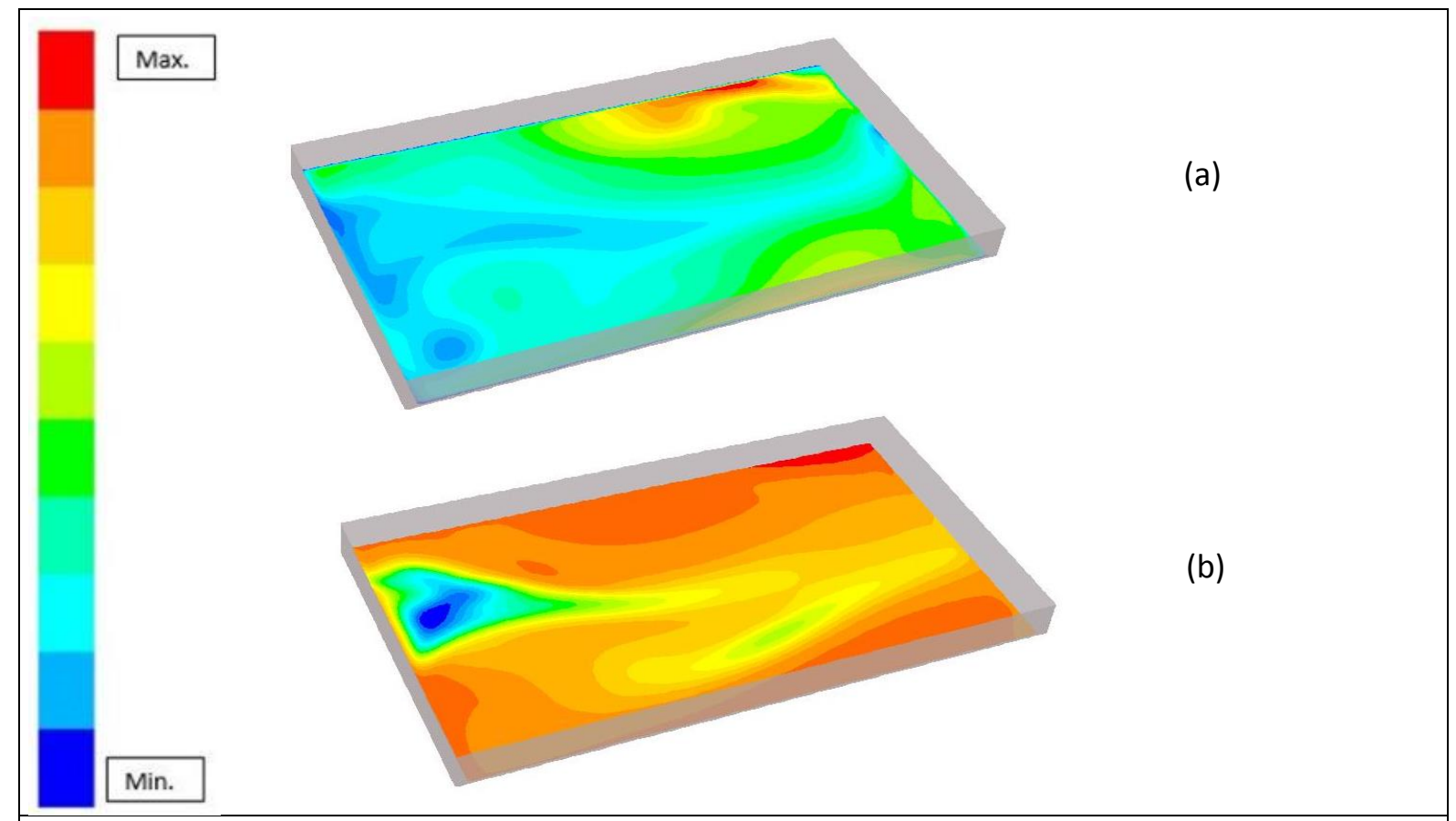

Figure 14. (a) Contours of velocity on a horizontal plane in the large tray (Min=0, Max=1.5 m/s) (b) Contours of air temperature on a horizontal plane in the large tray (Min=310 K, Max=330 K)

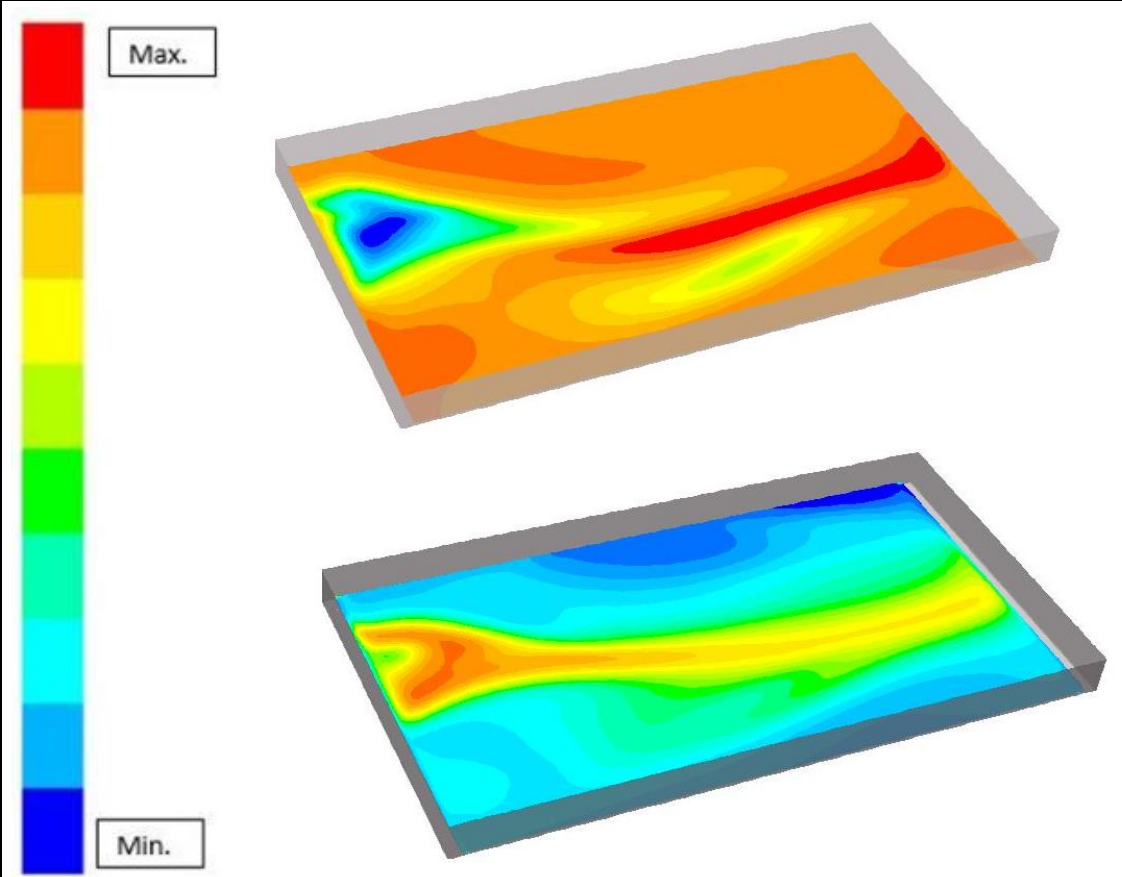

(a)

(b)

Figure 15 (a) Contours of mass fraction of water vapour in air on a horizontal plane in the large tray (Min=0.0141, Max=0.0147 ) (b) Contours of almond moisture content on a horizontal plane in the large tray for drying time of 8 hours (Min=0, Max=42)

The comparison of the simulated almonds average moisture content during the drying process of single tray of small and large-scale units is shown in Figure 16. The drying rate for a larger dryer is lower than the smaller unit despite maintaining the air flow rate per unit weight of almond same as that of smaller unit. It should be noted that the heating coil area also increased four times when the dryer was scaled 
and therefore the heat duty or heat input was also scaled four times for the larger dryer. The simulated results for the case of larger dryer filled with four trays are shown in Figure 17. It can be seen from Figure 17a that the drying rate with four trays is considerably lower compared to the single tray. This was mainly because of the same heat input as that of single tray despite increasing the total almonds being processed (since area of heating coil does not change with the number of trays). As heating coil temperature cannot be set to unrealistic value, it is essential to pre-heat the inlet air to maintain the total heat input per unit weight of almond same in all the cases. Appropriate pre-heating was represented by setting the inlet air temperature as $47^{\circ} \mathrm{C}$ to ensure that the air temperature at the measurement location is close to $55^{\circ} \mathrm{C}$. The simulated results with the pre-heated air are also shown in Figure 17a. With same heat input per unit weight of almonds, the overall drying rate has been considerably improved. It is, however, is still significantly lower than the single large tray simulation results. These simulations bring out the relevance of air temperature and heat source supplied in the dryer to achieve the desired drying characteristics. The variation of volume average moisture content for almonds in the four trays at a drying time of 1 hour is shown in Figure 17b. As the air flow from bottom to top, tray 1 being on the top has the highest moisture content. Contrary to the expectation that the bottom most tray will have lower moisture content, the last but one, tray 3 shows the least moisture content. This is because of the mal-distribution of air flow through different trays. The tray 3 is located closes to the inlet fan and therefore gets the largest air flow with lowest humidity. It therefore shows lowest moisture content. This highlights the importance and need for using detailed CFD simulations for identifying regions of inadequate air flow and temperature distribution which could be improved by appropriate design modifications. The approach and models presented here can be used for designing and scaling-up tray dryers.

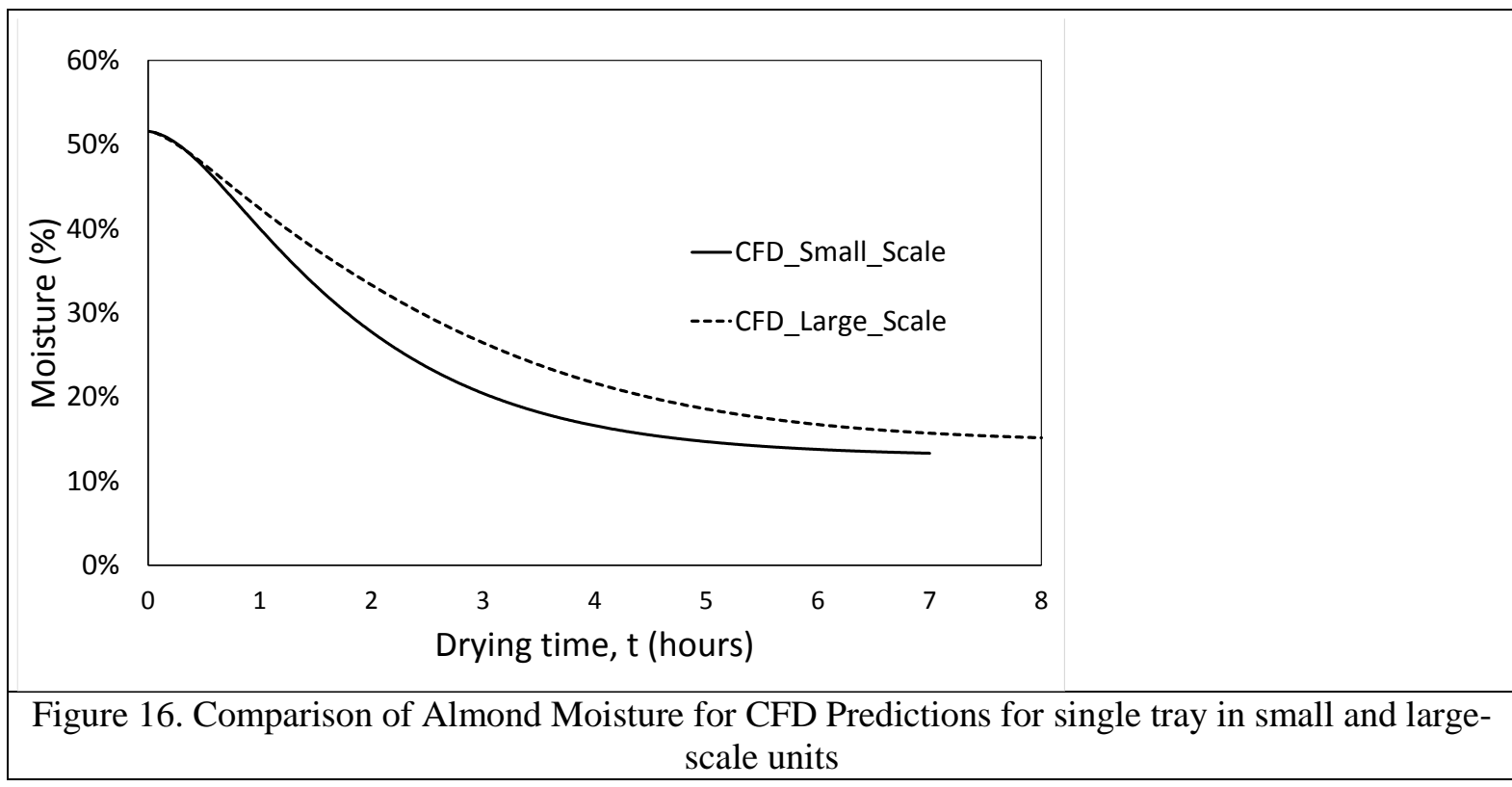




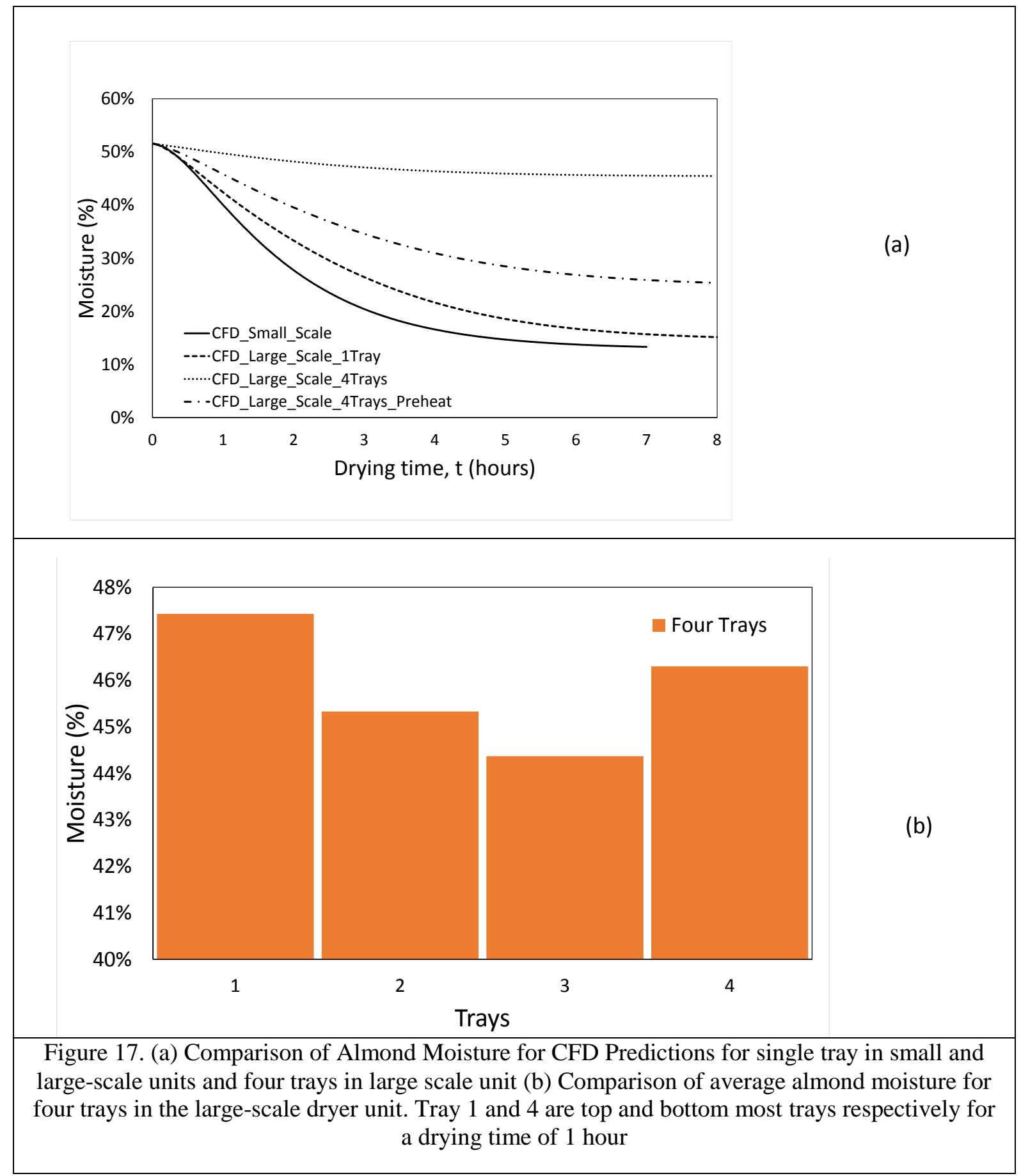

Figure 18a and 18b shows the air velocity and almond moisture across all the four trays for a largescale tray dryer unit. As the air inlet in the unit is in the bottom section, there is a high velocity zone at the inlet section. Also, there is a considerable distribution of almond moisture within each tray. Top most tray-1 has the highest almond moisture content as compared to all the other trays.

\section{Conclusions}

A step-by-step approach for modelling drying characteristics of single, multiple and large number of particles in a tray dryer configuration was developed. A comprehensive CFD model for simulating tray 
dryers was developed using the parameters estimated from single and multiple particles experiments and simulations. This fully coupled drying model was used to simulate flow field, distribution of temperature and moisture content of air and particles during the drying process. The influence of air quality, and velocity is incorporated in the drying model. For validating the developed drying model experiments with different configuration of almonds in tray dryer were performed. The measured outlet air humidity along with the moisture content of almonds at different sections in the tray dryer were compared with predicted values from CFD. The developed CFD model showed reasonably good agreement with the experimental data. CFD based simulations capture the impact of air flow pattern, air humidity and temperature to predict corresponding drying characteristics. Influence of the dryer configuration and mal-distribution of almonds on tray could be captured adequately by the developed CFD model. The developed drying model was then used to simulate drying characteristics of larger scale tray dryers. The results indicate that simplistic scaling rules like maintaining the same air flow rate per unit weight of almonds and same heat input per unit weight of almonds may not work adequately. CFD model and simulations provide significantly more information and insight which will facilitate design changes to ensure that product quality and dryer performance is maintained for different scales. The model and results presented here will be useful for design, scale-up and optimisation of industrial dryers.

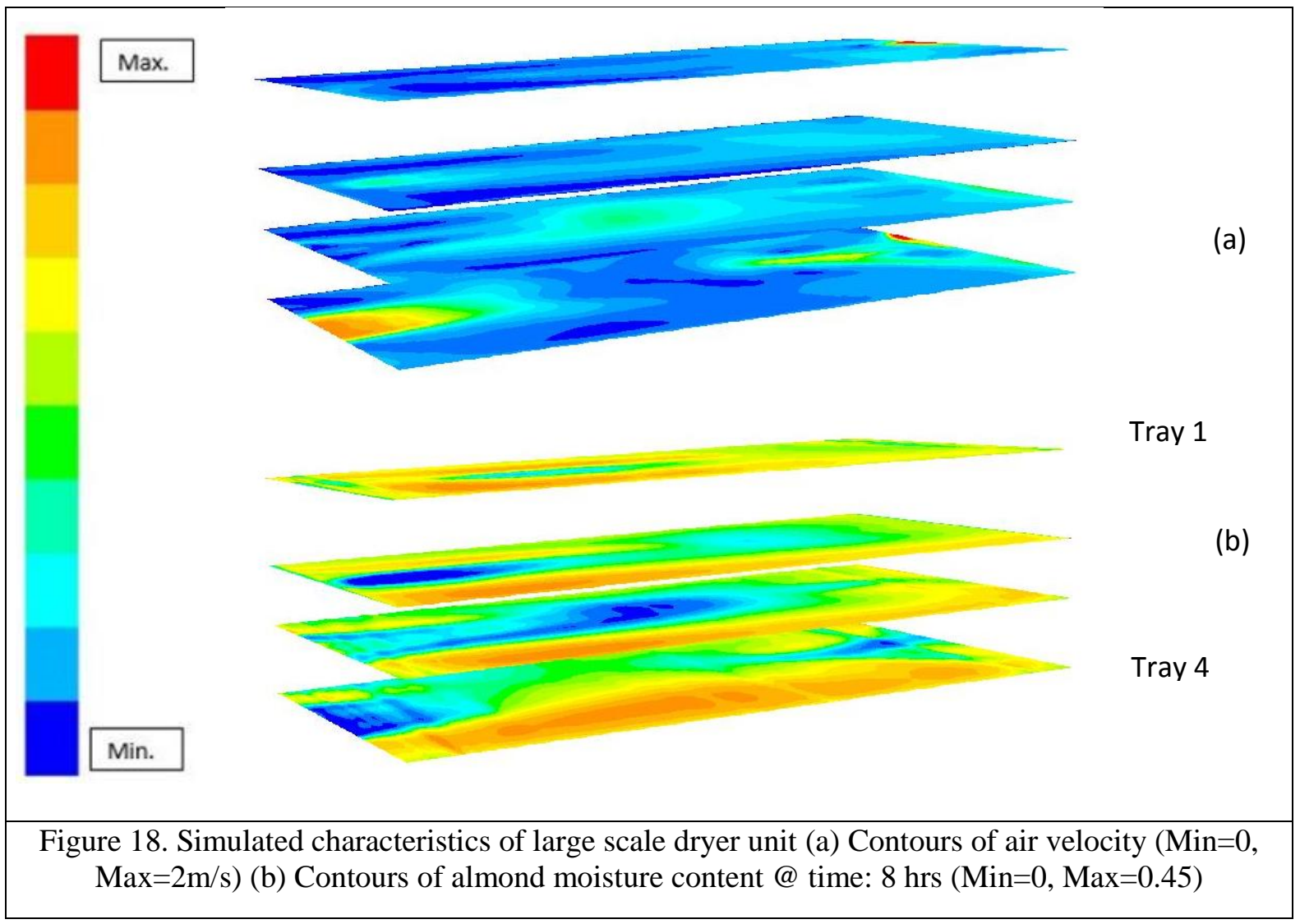




\section{Nomenclature}

\begin{tabular}{|c|c|c|c|c|c|}
\hline$A, B, C$ & Model constants & & $\mathrm{O}$ & $\begin{array}{l}\text { Empirically derived } \\
\text { constant }\end{array}$ & \\
\hline$a, b, c$ & Model constants & & $p$ & Pressure & $\mathrm{Pa}$ \\
\hline$A_{f}$ & Total area of holes & $\mathrm{m}^{2}$ & $p_{a}$ & Vapour pressure & $\mathrm{Pa}$ \\
\hline$A_{p}$ & Total area of plate & $\mathrm{m}^{2}$ & $p_{\text {sat }}$ & $\begin{array}{l}\text { Saturation vapour } \\
\text { pressure }\end{array}$ & $\mathrm{Pa}$ \\
\hline$A_{s v}$ & $\begin{array}{l}\text { Ratio of surface area to } \\
\text { volume }\end{array}$ & $\mathrm{m}^{2} / \mathrm{m}^{3}$ & $\mathrm{R}$ & $\begin{array}{l}\text { Universal gas } \\
\text { constants }\end{array}$ & $\mathrm{J} / \mathrm{Kmol.K}$ \\
\hline$C_{2}$ & Inertial resistance & $1 / \mathrm{m}$ & $r_{h}$ & Relative humidity & \\
\hline$C_{s}$ & $\begin{array}{l}\text { Mass concentration of water } \\
\text { vapour in solid }\end{array}$ & $\mathrm{kg} / \mathrm{m}^{3}$ & $S_{h}$ & Heat sink term & $\mathrm{kg} / \mathrm{m} \cdot \mathrm{s}^{3}$ \\
\hline$C_{v}$ & $\begin{array}{l}\text { Mass concentration of water } \\
\text { vapour in air }\end{array}$ & $\mathrm{kg} / \mathrm{m}^{3}$ & $S_{h p}$ & $\begin{array}{l}\text { Heat source for } \\
\text { almond temperature }\end{array}$ & $\mathrm{K} / \mathrm{s}$ \\
\hline$C_{p a}$ & Specific heat of air & J/kg.K & $S_{m}$ & $\begin{array}{l}\text { Mass source for water } \\
\text { vapour }\end{array}$ & $\mathrm{kg} / \mathrm{m}^{3} \cdot \mathrm{s}$ \\
\hline$C_{p s}$ & Specific heat of almond & J/kg.K & $t$ & Time & $\mathrm{s}$ \\
\hline$C_{p v}$ & $\begin{array}{l}\text { Specific heat of water } \\
\text { vapour }\end{array}$ & $\mathrm{J} / \mathrm{kg} . \mathrm{K}$ & $T$ & Temperature & K \\
\hline$D$ & Effective diffusivity & $\mathrm{m}^{2} / \mathrm{s}$ & $T_{a}$ & Air temperature & K \\
\hline$D_{p}$ & Mean particle diameter & $\mathrm{m}$ & $T_{p}$ & Solids temperature & $\mathrm{K}$ \\
\hline$F$ & Momentum Source Term & $\mathrm{kg} / \mathrm{m}^{2} \cdot \mathrm{s}^{2}$ & $v$ & Velocity & $\mathrm{m} / \mathrm{s}$ \\
\hline$h_{p}$ & Heat transfer coefficient & $\mathrm{W} / \mathrm{m}^{2} . \mathrm{K}$ & $x$ & direction & $\mathrm{M}$ \\
\hline$h_{v}$ & Latent heat of vaporization & $\mathrm{J} / \mathrm{kg}$ & $Y_{i}$ & Species mass fraction & \\
\hline $\mathrm{i}, \mathrm{j}$ & Indices & & & & \\
\hline$J_{i}$ & Diffusion flux of species & $\mathrm{kg} / \mathrm{m}^{2} . \mathrm{s}$ & $\rho$ & Density & $\mathrm{kg} / \mathrm{m}^{3}$ \\
\hline$k$ & $\begin{array}{l}\text { Almond thermal } \\
\text { conductivity }\end{array}$ & $\mathrm{W} / \mathrm{m} \cdot \mathrm{K}$ & $\rho_{p b}$ & Almond bulk density & $\mathrm{kg} / \mathrm{m}^{3}$ \\
\hline$k_{e f f}$ & $\begin{array}{l}\text { Effective thermal } \\
\text { conductivity }\end{array}$ & $\mathrm{W} / \mathrm{m} \cdot \mathrm{K}$ & $\varepsilon$ & Void fraction & \\
\hline$k_{m}$ & Mass transfer coefficient & $\mathrm{m} / \mathrm{s}$ & $\alpha$ & Permeability & $\mathrm{m}^{2}$ \\
\hline$L$ & Plate thickness & $\mathrm{M}$ & $\tau$ & Stress Tensor & $\mathrm{kg} / \mathrm{m} \cdot \mathrm{s}^{2}$ \\
\hline Le & Lewis number & & $\phi$ & Correction factor & \\
\hline$M_{e}$ & $\begin{array}{l}\text { Equilibrium moisture } \\
\text { content }\end{array}$ & & $\Phi_{k}$ & $\begin{array}{l}\text { Moisture content of } \\
\text { almond }\end{array}$ & $\mathrm{kg} / \mathrm{m}^{3}$ \\
\hline $\mathrm{n}$ & constant & & & & \\
\hline
\end{tabular}

\begin{tabular}{|l|l|}
\hline List of Tables & \\
\hline Table 1. & Equilibrium Moisture content for Almonds at 55 and $75{ }^{\circ} \mathrm{C}$ \\
\hline Table 2. & Chung-Pfost model constants for Almonds over range of 55 and $75{ }^{\circ} \mathrm{C}$ \\
\hline Table 3. & Antoine model constants for calculating saturation pressure \\
\hline Table 4. & Details of macros used in UDF \\
\hline
\end{tabular}




\begin{tabular}{|c|c|}
\hline List of Figures & \\
\hline Figure 1. & $\begin{array}{l}\text { (a) Schematic of Tray Dryer Setup, (b) Perforated Tray Details, showing the five } \\
\text { sampling locations }\end{array}$ \\
\hline Figure 2. & $\begin{array}{l}\text { (a) Photo of single tray completely filled with Almonds }(\sim 2 \mathrm{Kg}) \text { (b) Photo of half } \\
\text { tray filled with same amount of almonds }\end{array}$ \\
\hline Figure 3. & $\begin{array}{l}\text { (a) Detailed 3D model of Tray Dryer used in CFD Simulations. (b) Image of } \\
\text { Mesh around fan blades, heating coils and on the tray }\end{array}$ \\
\hline Figure 4. & $\begin{array}{l}\text { (a) Velocity contours on a vertical plane in the tray dryer unit }(\mathrm{Min}=0, \mathrm{Max}=0.17 \\
\mathrm{m} / \mathrm{s}) \text {, (b) Temperature distribution on a vertical plane in the tray dryer unit (Min= } \\
300 \mathrm{~K}, \mathrm{Max}=350 \mathrm{~K}\end{array}$ \\
\hline Figure 5. & $\begin{array}{l}\text { (a) Velocity vectors on a horizontal plane in the tray }(\operatorname{Min}=0, \operatorname{Max}=0.17 \mathrm{~m} / \mathrm{s} \text { ), } \\
\text { (b) Velocity vectors on a vertical plane in the tray (Min=0, Max=0.17 m/s) }\end{array}$ \\
\hline Figure 6. & $\begin{array}{l}\text { (a) Contours of mass fraction of water vapour in air on a horizontal plane in the } \\
\text { tray (Min }=0.02 \text {, Max }=0.06 \text { ), (b) Contours of mass fraction of water vapour in air } \\
\text { on a vertical plane in the tray (Min }=0.02, \operatorname{Max}=0.06 \text { ) }\end{array}$ \\
\hline Figure 7. & $\begin{array}{l}\text { Almonds Moisture (\%) Contours on a horizontal plane in the centre of almond } \\
\text { layer at (a) } 2 \text { hours of drying time, (b) } 7 \text { hours of drying time (Min=2\%, } \\
\text { Max }=30 \% \text { ) }\end{array}$ \\
\hline Figure 8. & $\begin{array}{l}\text { Specific Humidity Measurements at inlet and outlet of tray dryer, and CFD } \\
\text { Predictions for set temperature of } 55^{\circ} \mathrm{C}\end{array}$ \\
\hline Figure 9. & $\begin{array}{l}\text { Comparison of outlet air specific humidity for three set temperatures } 55,65 \text { and } \\
75^{\circ} \mathrm{C}\end{array}$ \\
\hline Figure 10. & $\begin{array}{l}\text { (a) Comparison of average almonds moisture at set temperature of } 55^{\circ} \mathrm{C} \text {, for } \\
\text { experimental measurements and volume average values from CFD simulation (b) } \\
\text { Comparison of average almonds moisture at five different sections for } \\
\text { experimental and CFD simulation values at drying time of } 2 \mathrm{hrs}\end{array}$ \\
\hline Figure 11. & $\begin{array}{l}\text { Comparison of Outlet air specific humidity for full tray at } 75^{\circ} \mathrm{C} \text {, with half tray at } \\
75{ }^{\circ} \mathrm{C}\end{array}$ \\
\hline Figure 12. & $\begin{array}{l}\text { (a) Comparison of Average Almond Moisture for Experimental and CFD } \\
\text { Predictions for Half-filled tray, set temperature } 75^{\circ} \mathrm{C} \text { (b) Comparison of average } \\
\text { almond moisture at five different sections in the tray at drying time of } 1 \mathrm{hr}\end{array}$ \\
\hline Figure 13. & $\begin{array}{l}\text { (a) Comparison of Velocity contours for full and half-filled tray CFD simulations } \\
\text { for a plane passing through the centre of almonds (Min }=0, \mathrm{Max}=0.17 \mathrm{~m} / \mathrm{s})(\mathrm{b}) \\
\text { Almonds Moisture }(\%) \text { Contours of almond moisture for full tray and half tray } \\
\text { CFD drying simulations (Min }=2 \%, \mathrm{Max}=30 \% \text { ) }\end{array}$ \\
\hline Figure 14. & $\begin{array}{l}\text { (a) Contours of velocity on a horizontal plane in the large tray }(\mathrm{Min}=0, \mathrm{Max}=1.5 \\
\mathrm{m} / \mathrm{s})(\mathrm{b}) \text { Contours of air temperature on a horizontal plane in the large tray } \\
(\mathrm{Min}=310 \mathrm{~K}, \mathrm{Max}=330 \mathrm{~K})\end{array}$ \\
\hline Figure 15. & $\begin{array}{l}\text { (a) Contours of mass fraction of water vapour in air on a horizontal plane in the } \\
\text { large tray (Min=0.0141, Max }=0.0147 \text { ) (b) Contours of almond moisture content } \\
\text { on a horizontal plane in the large tray (Min }=0, M a x=42 \text { ) }\end{array}$ \\
\hline Figure 16. & $\begin{array}{l}\text { Comparison of Almond Moisture for CFD Predictions for single tray in small and } \\
\text { large-scale units }\end{array}$ \\
\hline Figure 17. & $\begin{array}{l}\text { (a) Comparison of Almond Moisture for CFD Predictions for single tray in small } \\
\text { and large-scale units and four trays in large scale unit (b) Comparison of average } \\
\text { almond moisture for four trays in the large-scale dryer unit. Tray } 1 \text { and } 4 \text { are top } \\
\text { and bottom most trays respectively for a drying time of } 1 \text { hour }\end{array}$ \\
\hline Figure 18. & $\begin{array}{l}\text { (a) Contours of air velocity for four trays in the large scale dryer unit (Min }=0 \text {, } \\
\text { Max }=2 \mathrm{~m} / \mathrm{s} \text { ) (b) Contours of almond moisture for four trays in the large-scale dryer } \\
\text { unit for a drying time of } 8 \text { hours }\end{array}$ \\
\hline
\end{tabular}




\section{References}

1. A. Ayensu, Dehydration of food corps using a solar dryer with convective heat flow, Solar Energy 1997, 59121

2. V. T. Karathanos, V. G. Belessiotis, Application of a thin layer equation to drying data of fresh and semi-dried fruits. J. of Agri. Engg. Res. 1999, 74, 355

3. E. K. Akpinar, Y. Bicer, C. Yildiz, Thin layer drying of red pepper. J. of Food Engg. 2003, 59,99

4. L. R. Verma, R. A. Bucklin, J. B. Endan, F. T. Wratten, Effects of drying air parameters on rice drying models. Transactions of the ASAE 1985, 28, 296

5. A. Midilli, H. Kucuk, Z. Yapar, A new model for single layer drying. Drying Tech. 2002, 20 (7), 1503

6. M. Ranjbaran, B. Emaid, D. Zare, CFD Simulation of Deep-Bed Paddy Drying Process and Performance. Drying Tech. 2014, 32, 919

7. A. Kaya, O. Aydin, I. Dincer, Experimental and numerical investigation of heat and mass transfer during drying of Hayward kiwi fruits. J. of Food Engg. 2008, 88, 323

8. R. ElGamal, F. Ronsse, S. M. Radwan, J. G. Pieters, Coupling CFD and Diffusion Models for Analyzing the Convective Drying Behavior of a Single Rice Kernel, Drying Tech. 2014, 32 311

9. A. G. Chilka, V. V. Ranade, Drying of Almonds I: Single Particle, Ind. Chem. Eng. 2017, DOI: 10.1080/00194506.2017.1333464

10. A. G. Chilka, V. V. Ranade, Drying of Almonds II: Multiple Particles, Ind. Chem. Eng. 2017, DOI: $10.1080 / 00194506.2017 .1363672$

11. N. Colak, A. Hepbasil, Performance analysis of drying of green olive in a tray dryer, J. of Food Engg. 2007, 80, 1188

12. N. A. Aviara, L. N. Onuoha, O. E. Falola, J. C. Igbeka, Energy and exergy analyses of native cassava starch drying in a tray dryer, Energy, 2014, 73, 809

13. D. P. Margaris, A. G. Ghiaus, Dried product quality improvement by air flow manipulation in tray dryers, J. of Food Engg. 2006, 75, 542

14. A. Yasaman, A. Zomorodian, Applying CFD for designing a new fruit cabinet dryer Journal of Food Engg. 2010, 101, 8

15. S. Misha, S. Mat, M. H. Ruslan, K. Sopian, E. Salleh, Review on the Application of a Tray Dryer System for Agricultural Products, World Applied Sciences J. 2013, 22(3), 424

16. A. Kaya, O. Aydin, I. Dincer, Numerical modeling of heat and mass transfer during forced convection drying of rectangular moist objects, Int. J. of Heat and Mass Transfer 2006, 49, 3103

17. Ansys ${ }^{\circledR}$ Ansys Fluent-Solver v 14.5, Theory Guide 
18. P. L. Smith Jr., M. Van Winkle, Discharge coefficients through perforated plates at Reynolds number of 400 to 3,000, AIChE J., 1958, 4(3), 266

19. J.Y.Luo, R.I. Issa, A.D. Gosman. "Prediction of Impeller-Induced Flows in Mixing Vessels Using Multiple Frames of Reference" In I ChemE Symposium Series, 1994, 136, 595

20. H. Pahlevanzadeh, M. Yazdani, Moisture Adsorption Isotherms and Isosteric Energy For Almond, Journal of Food Process Engg. 2005, 28, 331

21. D. S. Chung, H. B. Pfost, Adsorption and desorption of water vapor by cereal grains and their products. Part I: Heat and free energy changes of adsorption and desorption. Transactions of the American Society of Agricultural Engineers, 1967, 10, 549

22. G. R. Thorpe, The application of computational fluid dynamics codes to simulate heat and moisture transfer in stored grains, J. of Stored, Pdts. Res., 2008, 44, 21

23. V. V. Ranade, Computational flow modeling for chemical reactor engineering, Academic Press, London. 2002 